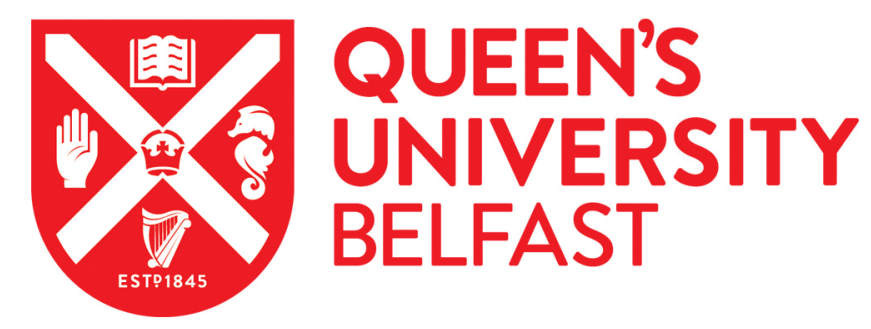

\title{
Late Holocene linkages between decade-century scale climate variability and productivity at Lake Tanganyika, Africa
}

Cohen, A. S., Lezzar, K. E., Cole, J., Dettman, D., Ellis, G. S., Gonneea, M. E., Plisnier, P. D., Langenberg, V., Blaauw, M., \& Zilifi, D. (2006). Late Holocene linkages between decade-century scale climate variability and productivity at Lake Tanganyika, Africa. Journal of Paleolimnology, 36(2), 189-209.

https://doi.org/10.1007/s10933-006-9004-y

Published in:

Journal of Paleolimnology

Document Version:

Publisher's PDF, also known as Version of record

Queen's University Belfast - Research Portal:

Link to publication record in Queen's University Belfast Research Portal

\section{General rights}

Copyright for the publications made accessible via the Queen's University Belfast Research Portal is retained by the author(s) and / or other copyright owners and it is a condition of accessing these publications that users recognise and abide by the legal requirements associated with these rights.

Take down policy

The Research Portal is Queen's institutional repository that provides access to Queen's research output. Every effort has been made to ensure that content in the Research Portal does not infringe any person's rights, or applicable UK laws. If you discover content in the Research Portal that you believe breaches copyright or violates any law, please contact openaccess@qub.ac.uk. 


\title{
Late Holocene linkages between decade-century scale climate variability and productivity at Lake Tanganyika, Africa
}

\author{
Andrew S. Cohen · Kiram E. Lezzar • \\ Julia Cole · David Dettman · Geoffrey S. Ellis · \\ Meagan Eagle Gonneea · Pierre-Denis Plisnier • \\ Victor Langenberg • Maarten Blaauw • \\ Derrick Zilifi
}

Received: 22 November 2005 / Accepted: 5 March 2006

(C) Springer Science+Business Media B.V. 2006

\begin{abstract}
Microlaminated sediment cores from the Kalya slope region of Lake Tanganyika provide a near-annually resolved paleoclimate record between $\sim 2,840$ and 1,420 cal. yr B.P. demonstrating strong linkages between climate variability and lacustrine productivity. Laminae couplets comprise dark, terrigenous-dominated half couplets, interpreted as low density underflows deposited from riverine sources during the rainy season, alternating with light, planktonic diatomaceous ooze, with little terrigenous component, interpreted as windy/dry season deposits. Laminated portions of the studied cores consist of conspicuous dark and light colored bundles of laminae couplets. Light and dark bundles alternate at decadal time scales. Within dark bundles,
\end{abstract}

A. S. Cohen $(\varangle) \cdot$ K. E. Lezzar $\cdot$ J. Cole $\cdot$ D. Dettman Department of Geosciences, University of Arizona, Tucson, AZ 85721, USA

e-mail: acohen@geo.arizona.edu

J. Cole

Department of Atmospheric Sciences, University of Arizona, Tucson, AZ 85721, USA

\section{G. S. Ellis}

Power, Environmental, and Energy Research Center, California Institute of Technology, Covina, CA 91722, USA

M. E. Gonneea

Woods Hole Oceanographic Institution, Woods Hole, MA 02543, USA both light and dark half couplets are significantly thinner than within light bundles, implying slower sediment accumulation rates during both seasons over those intervals.

Time series analyses of laminae thickness patterns demonstrate significant periodicities at interannual-centennial time scales. Longer time scale periodicities (multidecadal to centennial scale) of light and dark half couplet thicknesses are coherent and in some cases are similar to solar cycle periods on these time scales. Although laminae thickness cycles do not strongly covary with the actual $\Delta^{14} \mathrm{C}$ record for this same time period, two large $\Delta^{14} \mathrm{C}$ anomalies are associated with substantial decreases in both light and dark laminae thickness. In contrast to the multidecadal-

\section{P.-D. Plisnier}

Geology \& Mineralogy Department,

Royal Museum for Central Africa,

B-3080 Tervuren, Belgium

\section{Langenberg}

National Institute for Coastal and Marine

Management (RIKZ), 2500 EX The Hague,

The Netherlands

\author{
M. Blaauw \\ Centro de Investigación en Matemáticas, A.P. 402, \\ Guanajuato, Gto C.P. 36000, Mexico \\ D. Zilifi \\ Department of Geology, University of Zambia, \\ Lusaka, Zambia
}


centennial time scale, significant annual to decadal periodicities, which are broadly consistent with ENSO/PDO forcing and their impact on East African climate, are not coherent between light and dark half couplets. The coherency of light-dark couplets at decadal-centennial time scales, but not at shorter time scales, is consistent with a model of a long-term relationship between precipitation (recorded in wet season dark laminae thickness) and productivity (light laminae thickness), which is not manifest at shorter time scales. We hypothesize that this coupling results from long-term recharging of internal nutrient loading during wet periods (higher erosion of soil P) and reduced loading during drought intervals. The relationship is not expressed on short time scales during which the dominant control on productivity is wind-driven, dry season upwelling, which is uncorrelated with wet-season precipitation. Our record greatly extends the temporal record of this quasi-periodic behavior throughout the late Holocene and provides the first evidence linking decade- to century-scale episodes of enhanced productivity to enhanced precipitation levels and nutrient recharge in a productive tropical lake.

Keywords Lake Tanganyika · Varves · Paleoproductivity $\cdot$ Holocene paleoclimate $\cdot$ Solar forcing of climate $\cdot$ ENSO

\section{Introduction}

Sediments of the deep, stratified rift lakes of East Africa are known to be sensitive recorders of regional climate variability on seasonal time scales (Pilskaln 1989; Pilskaln and Johnson 1991; François et al. 1996; Johnson et al. 2001, 2002; Russell and Johnson 2005). Beyond the academic interest in deciphering climate history from the tropics, there are at least two reasons why a pressing societal need exists for obtaining such information from African lakes. First, given the severe impacts drought conditions have on the fragile economies of underdeveloped African countries, a clearer understanding of drought recurrence patterns would be extremely valu- able for the region (e.g., Cohen et al. 2005; Palacios-Fest et al. 2005a, 2005b). Late Holocene paleorecords from African lakes have in fact been used to provide precisely this type of information in prior studies (e.g., Verschuren 2000; Russell and Johnson 2005) although spatial coverage of such information remains extremely limited.

The second reason such records are required by lake managers is to understand the potential long-term (i.e., decadal-centennial time scale, beyond instrumental records) controls that climate exerts on lake level and productivity (e.g. Stager et al. 2005). From short duration instrumental records it is apparent that climate variability can impact primary production, for example through changes in wind-driven upwelling or seasonal intensification and weakening of stratification linked to temperature variability (e.g. Plisnier and Coenen 2001). Similarly, at much longer time scales, it is evident that many lakes responded to major climate shifts, such as the termination of Pleistocene glacial conditions and onset of Holocene warming, or the shorter duration changes associated with the beginning and end of the Younger Dryas, by dramatic changes in trophic state and total productivity (e.g. Birks et al. 2000; Johnson et al 2002). What is much less evident, and a subject of this study, is how lakes respond to decadal-centennial climate variability. As with drought forecasting, understanding climate impacts on lake productivity has immediate implications for African environmental management, since inland fisheries provide a very large proportion of animal protein throughout equatorial Africa in general and around Lake Tanganyika in particular (e.g. Mölsä et al. 2002).

In some meromictic lake sediments from tropical Africa, seasonality is registered by the deposition of terrigenous sediments (often with abundant allochthonous organic matter), derived from rainy season runoff, alternating with autochthonous diatom ooze, formed during the dry, windy season, when terrigenous sediment input is low (Pilskaln and Johnson 1991). In the windy season, increased nutrient supply from pulsed episodes of upwelling and seiche-driven mixing (Plisnier and Coenen 2001) favors the 
growth of larger phytoplankton, principally diatoms (Hecky 1991; Langenberg et al. 2003a), and settling sediment is dominated by pelagic particles that can readily settle through turbulent water (relatively large planktonic diatoms). Below the oxicline of this lake, where bioturbation is unimportant, this seasonality is expressed in the deposition of annually varved sediments, consisting of light (diatom rich, windy/dry season) and dark (terrigenous sediment, wet season) half couplets.

Despite our understanding of annual cycles in the East African lakes, there is still remarkably little information available on intermediate scale (decades to centuries) cycles of climatic variation and limnological response (see Stager et al. (2005) for a notable recent exception). Reliable instrumental records cover relatively brief intervals in East Africa (approx. past 100 years maximum and generally less). Data from some of these investigations demonstrate probable linkages between subdecadal events such as ENSO with lake mixing and productivity cycles (Plisnier 2000). However, projecting how decadal to century-scale variability in precipitation might affect lake productivity is not a matter of extrapolation from higher frequency events. For example, factors such as changes in external nutrient loading from watersheds may take decades to register with a sustained productivity response in a large lake whose annual productivity cycle is dominated by internal nutrient loading. This variability in lake response to climate at various time scales calls for an integration of paleolimnologic with limnologic data, using high-resolution paleorecords to bridge the gap. However, most paleolimnologic and paleoclimatologic studies of Holocene lake records in East Africa have been insufficiently resolved to investigate subdecadal to decadal events. And, where records of this resolution have been obtained, they have rarely been used to investigate natural linkages between climate and lake productivity. Some studies investigating sources of climate variability and their relationship to changing lake environmental conditions have concentrated on the directional changes associated with global climate change in the 20th century (O'Reilly et al. 2003; Verburg et al. 2003). Others have examined the relation- ship of lake level to precipitation, but have focused on the lake largely as an archive of external paleoclimate information rather than in terms of productivity responses to those external climate forcing events (e.g. Russell and Johnson 2005). Our motivation for this current study was to use a highly resolved Holocene paleoclimate record from Lake Tanganyika to better understand the climate-lake productivity linkage at time scales beyond what instrumental records can provide.

Lake Tanganyika, the focus of this study, is a deep, meromictic, tropical rift lake, which experiences an annual alternation of rainy/calm season (October-April) vs. dry/windy season (MaySeptember) conditions (Fig. 1). Although no sediment trap studies have yet been conducted in Lake Tanganyika, its similar limnologic and climatic characteristics to those of nearby Lake Malawi (Pilskaln and Johnson 1991; Patterson and Kachinjika 1995; François et al. 1996), coupled with its similarly laminated deposits in water depths below the oxicline (100-150 m) strongly suggests that the alternating accumulation of allochthonous and autochthonous sediments, described in detail below, represents annually deposited varves. Seasonal and interannual variability in laminae thickness, sediment geochemistry and paleontology provides a means of interpreting past changes in these driving mechanisms and linking them to internal lake biogeochemical processes (e.g., Anderson and Dean 1988; Lotter et al. 1997; Johnson et al. 2001; Wheeler et al. 2002). Although varve thickness records have commonly been subjected to time series analysis, most such studies have focused on the implications such data have for changing climatic regimes. Here we examine both the climatic implications of a tropical lake varve record and the consequences that our inferred paleoclimate record has for understanding the long-term delivery and cycling of nutrients (particularly phosphorus loading) and the resulting effects of such variable nutrient cycling on productivity. We argue that long term changes in algal community structure and diatom productivity cycles in deep, tropical meromictic lakes, like Tanganyika, may be strongly linked to decadal to century-scale climate cycles. 


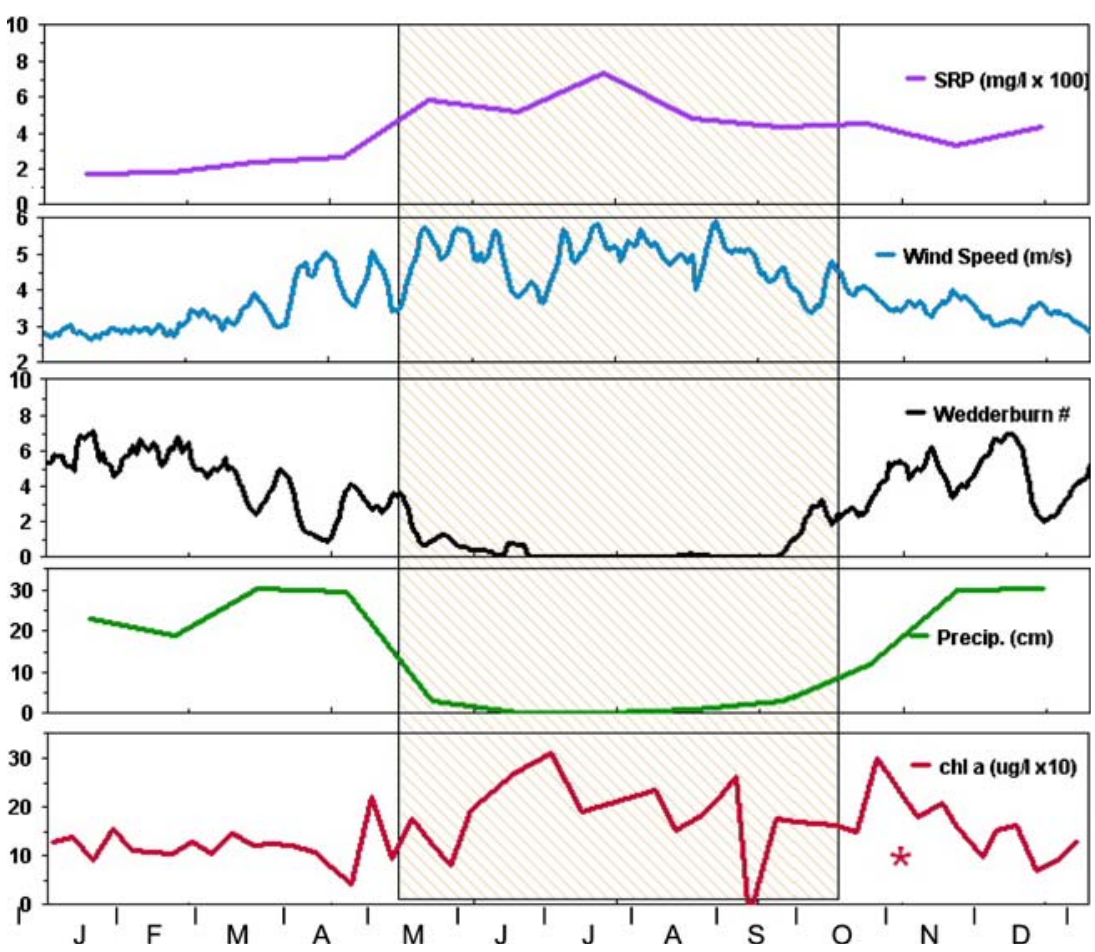

Fig. 1 Annual limnologic and climatic cycle in the southern portion of Lake Tanganyika. Typical interval of annual dry/windy season is diagonally shaded. All data except precipitation are from Mpulungu station, Zambia, approximately $250 \mathrm{~km}$ south of the Mahale Mountain coast study area, for the period 8/93-8/96, derived from Langenberg et al. (2003b). Soluble reactive phosphorus (SRP) concentrations in the epilimnion $(<40 \mathrm{~m})$ are monthly averages (monthly $n=2-9$ ). Wind speed and Wedderburn number (a dimensionless number describing

\section{Core site environment}

All cores examined in this study were collected from Lake Tanganyika on the Kalya Platform slope, on the eastern-central margin of the lake (Fig. 2). Core LT-00-02 was recovered from $309 \mathrm{~m}$ water depth at $6^{\circ} 33.154^{\prime} \mathrm{S}, 2^{\circ} 58.306^{\prime} \mathrm{E}$, and core NP01-MC01 from $303 \mathrm{~m}$ water depth at $6^{\circ} 33.177^{\prime} \mathrm{S}, 2^{\circ} 58.539^{\prime}$ E. Core LT-00-01 was collected closer to the coastline ( $\sim 5 \mathrm{~km}$ offshore, $\left.6^{\circ} 30.756^{\prime} \mathrm{S}, 30^{\circ} 01.062^{\prime} \mathrm{E}\right)$ from $128 \mathrm{~m}$ water depth, to better constrain depositional processes.

The coring sites are located on a $\sim 3 \%$ slope, approximately $9 \mathrm{~km}$ offshore from the southwest tip of the Mahale Mountain peninsula on the Kalya slope. Bottom waters at the deeper coring sites are permanently anoxic, with the oxicline water column stability and stratification strength, e.g. Imberger and Patterson, 1990) data are running weekly averages. Precipitation data are 1976-1989 means for Kasoge Station, Tanzania (Mahale Mountains), from Plisnier et al. (1996). Chlorophyll $a$ ( $\mathrm{chl} a$ ) measurements are expressed as $\mu \mathrm{g} 1^{-1} \times 10$. One chlorophyll outlier $\left(\right.$ marked $*$ ) measuring $9.86 \mu \mathrm{g} 1^{-1}$, resulted from a superficial blue-green algal bloom, which was demonstrably unrelated to upwelling

fluctuating between $100 \mathrm{~m}$ in the rainy (calm) season and $130 \mathrm{~m}$ in the windy and better mixed dry season. Therefore the more proximal LT-0001 site is periodically subject to oxygenation and turbidity flows, and is not consistently laminated. The Kalya slope receives significant siliciclastic sediment input from the adjacent Mahale Mountains to the north, especially via the perennial Lufubu and Lugonesi Rivers and the seasonal Msofwe, Mpanga, and Kininsa Rivers. Rainfall and runoff in this area are high, averaging $\sim 1,800 \mathrm{~mm} / \mathrm{yr}$, concentrated almost entirely during the rainy season (Fig. 1). Consequently, sediment discharge is highly seasonal down these rivers, with little discharge during the dry season and torrential floods during the rainy season. During the wet season, winds from the $\mathrm{NE}$ 


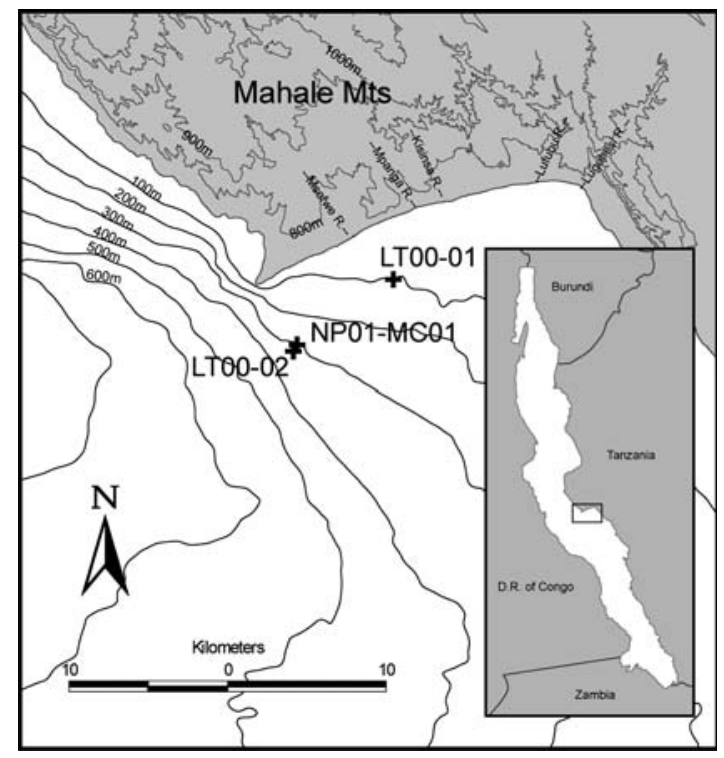

Fig. 2 Map of central Lake Tanganyika showing locations of cores LT-00-01, LT-00-02 and NP01-MC01 and adjacent topography/bathymetry. Inset. Location map of core site in Lake Tanganyika region

generate WSW longshore flow along the south Mahale coastline, in the general direction of the coring sites. Coastal currents, coupled with high discharges of sediment-laden, cold river waters, cause the formation of underflows (low density turbidity flows). Core LT-00-01 largely comprises distal, clay-rich (pelletized) turbidites derived from this downslope deposition, in contrast to the less disturbed stratigraphy of core LT-00-02, the focus of this study.

\section{Methods}

Coring and core handling

In 2000 and 2001 we collected cores from the eastcentral part of Lake Tanganyika, in a region sensitive both to seasonal variations in runoff from the adjacent $\sim 2,500 \mathrm{~m}$ Mahale Mountains and to strong seasonal upwelling and increases in diatom productivity (Fig. 2). Cores LT-00-01 and LT-00-02 (the latter the primary focus of this paper) were collected using a $2 \mathrm{~m}$ Benthos gravity corer, in July, 2000. Both cores were inspected for sediment disturbance and stored upright prior to being opened, sectioned and marked for laminae bundle boundary positions (discussed below) at the Tanzania Fisheries Research Institute's Kigoma Station. All "uncorrected" depth measurements discussed below refer to actual measured depths below the top of the core liner. Because the upper sediment water interface was not recovered in core LT-00-02, and the uppermost sediments were slightly disturbed, we returned to the coring area in 2001, using a Hedrick-Marrs multicorer, to sample the sediment-water interface (core NP01-MC01) and correlate with the laminated interval of Core LT-00-02. Doing this allowed us to determine the amount of overpenetration in the LT-00-02 core $(21 \mathrm{~cm})$ which was subsequently corrected in further analyses (referred to in the text as "corrected" depths). Because of its nearly continuous laminated structure throughout its lower $80 \%$, core LT-0002 was chosen for the more detailed analyses described here. The surficial sediments at the coring site are only discontinuously laminated for unknown reasons, but perhaps the result of episodic ventilation. Therefore, they were not subjected to the detailed laminae thickness analysis discussed here.

\section{Sedimentological analysis}

We logged and photographed cores LT-00-01, LT-00-02 and NP01-MC01, prepared smear slides for diatom and organic matter observation, and performed loss on ignition (LOI) measurements on all cores immediately upon opening all cores. LOI burns were conducted on oven-dried $\left(60^{\circ} \mathrm{C}\right)$ samples at $550^{\circ} \mathrm{C}$ (total organic carbon, TOC) and $925^{\circ} \mathrm{C}$ (total inorganic carbon, TIC). LOI percentages were converted to TOC and TIC percentage estimates using 0.40 and $0.27 X$ correction factors respectively. Core LT-00-02 was taken to the University of Arizona for image analysis and subsampled for total phosphorus (TP) analysis (spectrophotometric analysis using microwaveacid digestion). Supplementary total phosphorus measurements on waters from the lake, influent river water, and precipitation were made spectrophotometrically (pressure boiling, acid persulphate method). We measured half couplet thicknesses using an Olympus ${ }^{\circledR}$ SZH stereomicroscope, with a high resolution Pulnix ${ }^{\circledR}$ digital 
camera (0.03 $\mathrm{mm}$ precision). All thickness measurements were extracted manually using Optimas ${ }^{\circledR}$ ver. 5.2 software.

Geochronometry, age modeling and time series analysis

Eight samples, representing seven stratigraphic horizons evenly spaced through the continuously laminated portion of core LT-00-02, were submitted to the University of Arizona's Accelerator Mass Spectrometry Laboratory for ${ }^{14} \mathrm{C}$ age determination. All ${ }^{14} \mathrm{C}$ age dates were converted to calendar age dates using CALIB 5.0.1html (Stuiver et al. 2005) and the calibration curve IntCal04 (Reimer et al. 2004). Because of known reservoir effects of the deep and slowly mixing hypolimnion of Lake Tanganyika, we collected two samples from one stratigraphic level (139.5$139.6 \mathrm{~cm}$ uncorrected depth down core). One was a bulk organic carbon sample and the other terrestrial wood, the latter assumed to lack a reservoir effect signal (its terrestrial origin is also confirmed by its much more negative $\delta^{13} \mathrm{C}$ value relative to other bulk organic matter samples from the lake). We used the offset between the two ${ }^{14} \mathrm{C}$ ages $\left(458{ }^{14} \mathrm{C}\right.$ yr $)$ to correct the remaining bulk organic matter age dates. The smaller offset between this estimate and earlier reservoir effect estimates (e.g. $650 \pm 60 \mathrm{yr}$ in Cohen et al. 1997) in part results from natural variability in reservoir time duration through the Holocene and in part from an improved statistical methodology in the current study. In the current study the difference in the uncalibrated ${ }^{14} \mathrm{C}$ ages between the bulk and wood samples was calculated first, and this offset was used to derive a calendar age offset for all remaining bulk samples, whereas in the earlier study the calendar ages were calculated first from both the wood and bulk dates and an offset was derived from the mean calendar age differences.

With the exception of the lowest portion of the laminated core interval, there is a statistically allowable match between the midpoints of the $2 \sigma$ calibrated ranges of the ${ }^{14} \mathrm{C}$ dated depths and the varve years corresponding to these depths. A least squares linear curve with slope 1 (where $n$ lamination couplets equal $n$ calendar years) gives an $r^{2}$ of 0.99 . We therefore can conclude that for this interval the laminations represent true annual varves, and we treat them as such for subsequent time series analysis and sedimentation rate discussion. A discrepancy in laminae count vs. ${ }^{14} \mathrm{C}$ derived calendar year count does exist in the lowest dated part of the core (i.e., a curve of slope 1 cannot connect the calibrated range of the lowest ${ }^{14} \mathrm{C}$ date with the other calibrated ranges) resulting in a significantly smaller number of laminae couplets than the $2 \sigma{ }^{14} \mathrm{C}$ age range will allow. This may result from either a higher proportion of lake-derived materials in the lowest bulk sample (changing the ${ }^{14} \mathrm{C}$ year vs. calendar year offset), or from amalgamation of some laminations, or both. Prior research suggests that localizing offsets between varve counts and ${ }^{14} \mathrm{C}$ age spreads is a more appropriate means of addressing such discrepancies, as opposed to spreading the offset cumulatively across the entire varved record and thereby potentially obscuring real temporal patterns (e.g. Tian et al. 2005). Because of the uncertainty associated with its true duration, we have therefore eliminated the lowest portion of the ${ }^{14} \mathrm{C}$-dated laminated portion of the core from subsequent time series analyses and treat the remainder of the record as being annually varved with no significant gaps.

The varve count provides a floating chronology of $1,421 \mathrm{yr}$ duration. Because of the inherent uncertainties associated with all ${ }^{14} \mathrm{C}$-based dates we affixed this floating chronology using a least squares approach, comparing all possible positions of the floating chronology vs. midpoints of the $2 \sigma{ }^{14} \mathrm{C}$-based calendar ages, under the assumption that the laminations were annual. The best fit (shown in Fig. 3) yielded an equation of

$$
\begin{aligned}
& \text { calendar year }=3,046-\text { varve year } \\
& \left(r^{2}=0.991824\right)
\end{aligned}
$$

We recognize that not all $2 \sigma$ calibrated ranges touch the age model and that a line with a lower slope (i.e., inconsistent with a 1 lamination $=1$ calendar year model) would fit slightly better. However, the precise widths and positions of the calibrated ${ }^{14} \mathrm{C}$ ranges are uncertain, as they depend on the size of the reservoir effect, which could only be estimated from the single pair of 


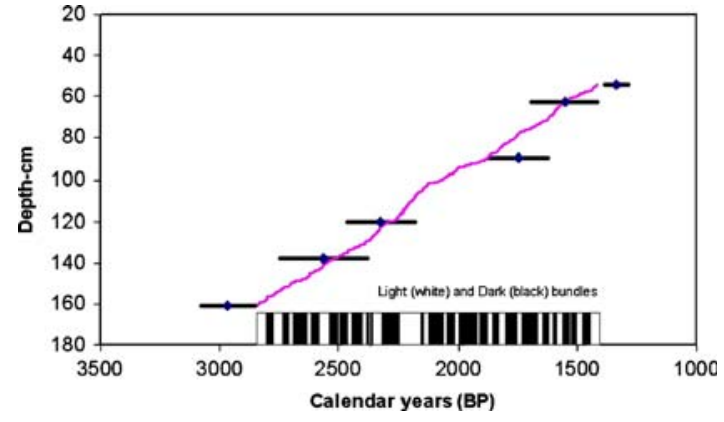

Fig. 3 Best fit age-depth model for LT-00-02, combining ${ }^{14} \mathrm{C}$-based calendar year age estimates (corrected for reservoir carbon effects) and an assumption of annual varve accumulation for the displayed interval

coeval terrestrial/bulk radiocarbon dates available. Given these uncertainties the ${ }^{14} \mathrm{C}$ dates are consistent with our assumption of an annual deposition of laminae couplets. We used this best fit to place our varve counted core interval in absolute time and for all subsequent discussion of climate history, recognizing that uncertainty remains in the exact anchoring dates of the varve chronology.

Prior to spectral analysis, we natural logtransformed all laminae thickness data, to reduce the skewness of the datasets. Spectral and cross spectral analyses were performed on annual thickness records for light and dark half couplets on both raw and log-transformed thickness data, using a multiple taper method with red-noise assumptions (Mann and Lees 1996). Only the results from the log-transformed data are presented here, as they are not significantly different from the raw data results. We also performed cross-spectral analysis between the laminae thickness data and $\Delta^{14} \mathrm{C}$ residual data $(1,000-\mathrm{yr}$ residuals from IntCal 2004; Reimer et al. 2004) at five-year resolution. All spectral, cross-spectral and coherence levels were compared for significance against a $90 \%$ confidence level (error fit to $\log$ spectrum).

\section{Results}

Core stratigraphy

The cores studied here collectively provide a contrast of depositional settings across the Kalya slope (Figs. 2, 4), from the oxic/anoxic transition (LT-00-01) where more proximal muddy turbidite deposition dominates the stratigraphy, to deeper anoxic settings (LT-00-02 and NP01-MC01) where only the most distal underflows are deposited along with pelagic diatom oozes.

LT-00-01 $(115 \mathrm{~cm})$ comprises four lithofacies. A layered clay (115-105 cm below the core top) consists of $0.25 \mathrm{~cm}$ thick dark and light olive, gray muds with relatively low TOC concentrations (mean $4.17 \%$ ). This facies is similar to all other facies analyzed in that it has low TIC concentrations, averaging about $0.7 \%$. Between 105 and $73 \mathrm{~cm}$, the second facies is dominated by alternating layers of fecal pellet-rich muds in sharp contact with light gray, massive clay layers $1-3 \mathrm{~cm}$ thick. These fine grained siliciclastic units, which appear to be distal (low density) turbidites, are occasionally interrupted by diatom-rich clays. TOC values average $5.25 \%$ for this interval and are similar in facies 3 above. From 73 to $46 \mathrm{~cm}$ the third facies consists of a diatom-rich mud, with yellow-gray diatomaceous horizons alternating with gray, clay rich layers on a cm-scale. This unit appears to have formed dominantly as distal turbidites, but perhaps with greater secondary reworking by benthic organisms during a prolonged period of bottom oxygenation. Facies 4 $(46-0 \mathrm{~cm})$ is similar to facies 2 above, comprising mostly layered fecal pellet-rich muds and more massive muds, interpreted as unbioturbated distal turbidites. TOC values average $4.88 \%$. However, this interval is interrupted by a structureless sandy silt lens $(30-23 \mathrm{~cm})$, which probably reflects an interlude of increased downslope transport and/or slumping.

LT-00-02 (172 cm, n.b., all depths given in this paragraph are relative to core liner, uncorrected for overpenetration) includes three lithofacies. From 172 to $156 \mathrm{~cm}$ below the top, the core consists of silty, diatomaceous, dark olive gray clays, with occasional diatom ooze laminations. TOC values for this facies (mean $6.31 \%$ ) and for other portions of the core are somewhat higher than for LT-00-01, reflecting LT-00-02's more distal location relative to coastal siliciclastic sediment sources and increased offshore organic matter contribution. From 156 to $46 \mathrm{~cm}$ the core consists of continuously laminated couplets of dark gray 
and yellow gray laminae with slightly higher TOC content than in the underlying facies (mean $6.78 \%$ ). This is the facies analyzed in detail in subsequent sections of this paper. The dark-gray mud (clayey silt) half couplets comprise a mixture of terrigenous grains, small planktonic and broken benthic diatoms, sponge spicules, and fine terrestrial plant debris, whereas the lighter colored, flocculated, diatomaceous silts have little siliciclastic or terrestrial organic debris and are mostly planktonic diatoms (Stephanodiscus and large, elongate Nitzchia). Individual half couplets are very thin $(0.01-1 \mathrm{~mm})$, but usually quite continuous across the cores. The couplets are organized into prominent light and dark colored bundles, organized on a $1-5 \mathrm{~cm}$ scale, coupled with alternately thicker (in light bundles) and thinner (in dark bundles) couplets (Fig. 4). The upper $46 \mathrm{~cm}$ of the core is also laminated and organized in similar bundles, although the laminae are thicker, largely because of considerably higher water content. This facies displayed higher (and more variable) TOC content, especially in the upper $20 \mathrm{~cm}$, where values rise abruptly to $7-10 \%$, and some portions of this uppermost zone are unlaminated. The increased water content caused coring related disturbance in the uppermost por- tion of this zone, making most of this section difficult to describe in detail. Only the interval between 46 and $29 \mathrm{~cm}$ of this uppermost facies could be analyzed at the individual couplet level.

NP01-MC01 $(49 \mathrm{~cm})$ displays a similar suite of lithofacies to those observed in LT-00-01, with alternating dark and light bundles of laminae couplets. However the uppermost portion of the core is discontinuously laminated, encompassing some massive (probable distal turbidite) units, in addition to the bundled laminae. The lowermost three bundles of NP01-MC01 could be correlated with the top three bundles of LT-00-01 on the basis of bundle thickness patterns, allowing us to estimate that the core top of LT-00-01 overpenetrated the sediment-water interface by approximately $21 \mathrm{~cm}$.

\section{Geochronometry}

Results from our ${ }^{14} \mathrm{C}$ analyses from Core LT-0001 are presented in Table 1 . The fully laminated portion of the core spans an interval of approximately 3,700-1,200 cal yr B.P. However, as discussed in the methods section, we have restricted our time series analysis to the 2,838-1,418 cal yr B.P. interval, during which the laminae counting

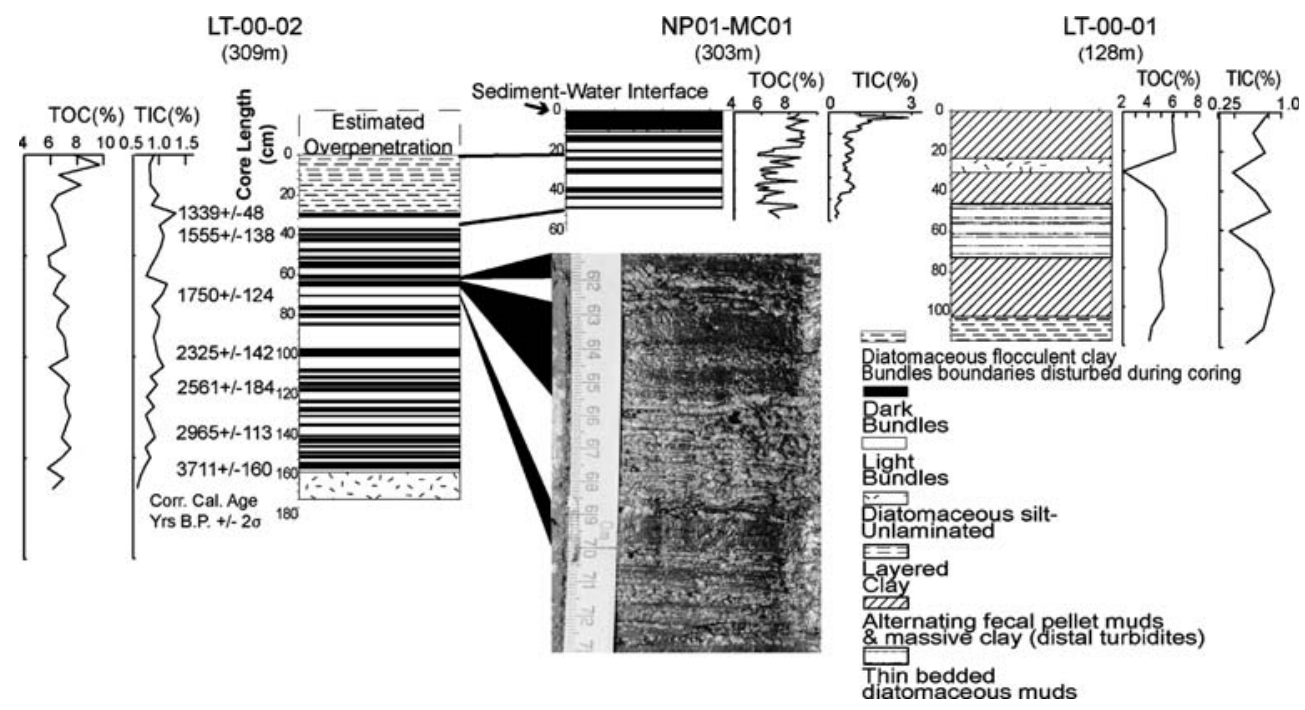

Fig. 4 Core stratigraphy, including TOC/TIC for cores LT-00-01, LT-00-02, and NP01-MC01 and inset photo of a section of core LT-00-02 showing the strong light/dark bundling pattern characteristic of microlaminated deposits at this site (black and white polygons show correlation of photo to core stratigraphy) 
Table $1{ }^{14} \mathrm{C}$ AMS dates used in this study

\begin{tabular}{|c|c|c|c|c|c|c|c|c|c|}
\hline $\begin{array}{l}\text { UA-AMS } \\
\text { Lab. \# }\end{array}$ & Material & $\begin{array}{l}\text { Core depth } \\
\text { range/mean } \\
(\mathrm{cm})\end{array}$ & $\begin{array}{l}\text { Depth below } \\
\text { lake floor } \\
(\mathrm{cm})^{1}\end{array}$ & $\delta^{13} \mathrm{C}$ & $\begin{array}{l}\text { Fraction } \\
\text { modern }\end{array}$ & $1 \sigma$ & $\begin{array}{l}{ }^{14} \text { C Age } \\
\text { B.P. } \pm 1 \sigma\end{array}$ & $\begin{array}{l}\text { Corrected }{ }^{14} \mathrm{C} \\
\text { age }^{2} \text { B.P. }\end{array}$ & $\begin{array}{l}\text { Corrected } \\
\text { calendar } \\
\text { age } \pm 2 \sigma^{3} \text { B.P. }\end{array}$ \\
\hline AA52983 & $\mathrm{BOM}^{4}$ & $36.7-29.1 / 32.9$ & 53.9 & -20.8 & 0.7903 & 0.0037 & $1891 \pm 37$ & 1433 & $1,339 \pm 48$ \\
\hline AA52986 & $\mathrm{BOM}$ & $43.1-40.4 / 41.8$ & 62.8 & -21.1 & 0.7685 & 0.0037 & $2,115 \pm 39$ & 1657 & $1,555 \pm 138$ \\
\hline AA41658 & $\mathrm{BOM}$ & 68.75 & 89.75 & -21.1 & 0.7525 & 0.0043 & $2,285 \pm 46$ & 1827 & $1,750 \pm 124$ \\
\hline AA41659 & $\mathrm{BOM}$ & 99.2 & 120.2 & -21.2 & 0.7066 & 0.0034 & $2,790 \pm 38$ & 2332 & $2,325 \pm 142$ \\
\hline AA52985 & $\mathrm{BOM}$ & $118.3-115.7 / 117.0$ & 138.0 & -21.7 & 0.6907 & 0.0034 & $2,973 \pm 40$ & 2515 & $2,561 \pm 184$ \\
\hline AA40385 & Wood $^{5}$ & 139.5 & 160.5 & -29.4 & 0.7018 & 0.0042 & $2,845 \pm 48$ & 2845 & $2,965 \pm 119$ \\
\hline AA40386 & $\mathrm{BOM}$ & 139.5 & 160.5 & -21.7 & 0.6628 & 0.0033 & $3,303 \pm 40$ & 2,845 & $2,965 \pm 113$ \\
\hline AA52984 & $\mathrm{BOM}$ & 157.9-155.3/156.6 & 177.6 & -22.0 & 0.6163 & 0.0057 & $3,888 \pm 74$ & 3430 & $3,711 \pm 160$ \\
\hline
\end{tabular}

${ }^{1}$ Corrected for $21 \mathrm{~cm}$ overpenetration, as determined by correlation with multicore NP01-MC01

${ }^{2}$ Using a lake old-carbon reservoir correction factor of $458{ }^{14} \mathrm{C}$ years, as discussed in the text

${ }^{3}$ Using CALIB5.0 (http://www.radiocarbon.pa.qub.ac.uk/calib/)

${ }^{4} \mathrm{BOM}=$ bulk organic matter

${ }^{5}$ Terrestrial sample and source of correction factor

is statistically consistent with a "one year = one laminae couplet" model within the uncertainty of the radiocarbon dates.

Laminae couplet and bundle interpretations

The prominent and repetitive light/dark structure of the laminated portions of LT-00-01 and NP01MC01 indicates a rhythmic depositional process. We interpret the dark half-couplets to represent rainy season accumulation, when terrigenous material and previously deposited nearshore sediments, including benthic diatoms, are transported offshore and downslope. We base this interpretation on the sedimentologic and paleoecologic contrasts between the half couplets, as well as the results of coupled sediment trap and short core studies from nearby Lake Malawi (Pilskaln 1989; Pilskaln and Johnson 1991; François et al. 1996), a rift lake with limnological properties and annual climatic cycles that are very similar to those of Lake Tanganyika (Fig. 1). In that lake, formation of annual laminations is most consistent in the deep water environments of the northern end of the lake, adjacent to the wettest part of the lake's catchment. This region of strong sediment delivery during the wet season from terrigenous sources is very similar to the Mahale region of Lake Tanganyika.
Lake Malawi studies also indicate that thickness variation between dark half couplets is driven by interannual variation in precipitation (wetter years $=$ thicker dark layers). During the windy/dry season, accumulation is restricted to large diatoms because terrigenous input is low, surface waters are turbulent, and diatom production is high. Interannual variation in light layer thickness (Fig. 5) may be caused by several factors, since diatom accumulation represents the balance between production and dissolution. However, thin light layers do not contain noticeably more corroded diatom frustules, making large interannual variations in dissolution an unlikely explanation for interannual thickness variations. It may be significant in this regard that most diatoms in light layers are organized in flocs, probably bound by diatom-secreted mucus, which may enhance the settling of these diatom clusters. In contrast, these flocs do not occur in the dark half couplets, where diatoms occur as isolated frustules and fragments. Most likely, interannual variation in light layer thickness is a function of near-surface diatom productivity, which is driven by more intense wind mixing that increases available nutrients and hence diatom productivity and accumulation.

Deep water sediments from Lake Tanganyika display variable types of lamination structure, 
Fig. 5 Laminae thicknesses (light and dark half couplets and combined light + dark) and laminae bundles vs. age for core LT-00-02. Dark bundles are inferred to represent periods of drought/low diatom productivity and light bundles wetter periods with higher diatom productivity. Orange arrows mark major drought intervals recorded in the Lake Edward Mg-calcite record, from Russell (pers. comm., 2005) and Russell and Johnson (2005)
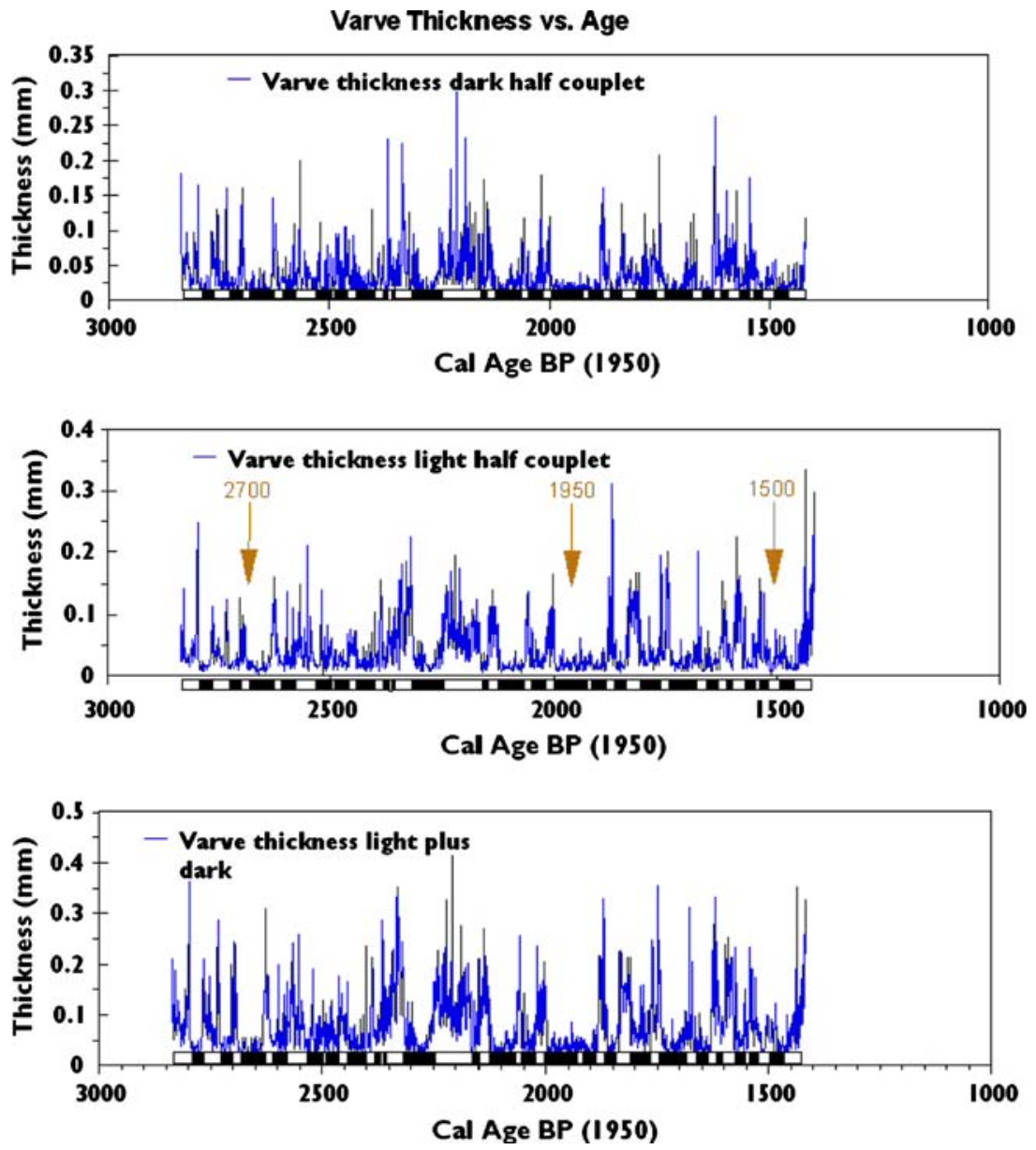

from sediments that are discontinuously laminated (Zilifi and Eagle 2000) to sediments that, although continuously laminated, nevertheless show strong indications that the laminae are not the result of annual cycles of deposition (e.g. Francus et al. 2003), to the rhythmic laminae couplets described here. It is clear that not all depositional settings within Lake Tanganyika are favorable for the accumulation of annual varves. Some sites are too shallow and subject to periodic bioturbation or frequent current reworking. Others are too deep, located too far offshore and/ or are adjacent to coasts with too little input of terrigenous sediment, and are therefore subject to sediment amalgamation. Yet others are adjacent to steep slopes, causing episodic accumulation of distal turbidites. In contrast to these constraints, the Kalya slope environment at the LT-00-02 core site is favorably located for amplifying an annual signal, given its strong seasonality (in the wettest region of the lake basin), gentle slope, distance from localized, continuous upwelling, and intermediate depth.

At the scale of laminar bundles, there is a strong relationship between bundle type and thicknesses of both light and dark half couplets. Both light and dark half couplets are significantly thicker in light bundles than in dark bundles (Table 2). This relationship drives an overall high correlation between light and dark bundle thickness on the scale of the full record (Table 3 ). However, within light or dark bundles, light and dark half couplets are uncorrelated. Even the best correlation obtainable, using an exponential regression relationship, yields $r^{2}$ values of only 0.128 and 0.085 within light and dark bundles respectively. The lack of correlation indicates that a relatively thick dark (wet season) half couplet may be followed by a relatively thick or thin light (dry season) half couplet. 
Table 2 Decadal scale bundle characteristics

\begin{tabular}{lllllll}
\hline $\begin{array}{l}\text { Bundle } \\
\text { type }\end{array}$ & $\begin{array}{l}\text { Laminae half } \\
\text { couplet type }\end{array}$ & $\begin{array}{l}\text { Mean thickness } \\
\pm 1 \sigma(\mathrm{mm})\end{array}$ & $\begin{array}{l}\text { Mean \# } \\
\text { laminae per } \\
\text { bundle } \pm 1 \sigma\end{array}$ & $\begin{array}{l}\text { Mean bundle } \\
\text { thickness } \pm 1 \sigma(\mathrm{cm})\end{array}$ & $\begin{array}{l}\text { Mean bundle } \\
\text { duration } \pm 1 \sigma\end{array}$ & $\begin{array}{l}\text { Mean TP flux } \\
\pm 1 \sigma\left(\mu \mathrm{cm}^{-2} \mathrm{yr}^{-1}\right) \\
\text { modern }=\sim 10\end{array}$ \\
\hline Light & Dark & $0.53 \pm 0.43$ & $23.5 \pm 19.0$ & $3.27 \pm 2.34$ & $23.53 \pm 19.02$ & $11.42 \pm 1.65(n=5)$ \\
& Light & $0.67 \pm 0.49$ & $33.6 \pm 17.6$ & $2.16 \pm 1.25$ & $33.57 \pm 17.57$ & $6.04 \pm 1.11(n=5)$ \\
Dark & Dark & $0.27 \pm 0.24$ & & & & $28.55 \pm 18.84$ \\
& Light & $0.25 \pm 0.17$ & & & & \\
\hline
\end{tabular}

Table 3 Correlation matrix of laminae half-couplet and total annual (light + dark) thickness data and potential solar forcing variables

\begin{tabular}{llllll}
\hline & Dark & Light & Total & $\Delta^{14} \mathrm{C}$ residual & Sunspot \\
\hline Dark & - & $0.739 * * *$ & $0.902 * * *$ & $-0.197 *$ & 0.099 \\
Light & & - & $0.953 * * *$ & $-0.242^{* *}$ & 0.111 \\
Total & & - & $-0.244 * *$ & 0.114 \\
$\Delta^{14} \mathrm{C}$ residual & & & & - & $-0.671^{* * *}$ \\
\hline
\end{tabular}

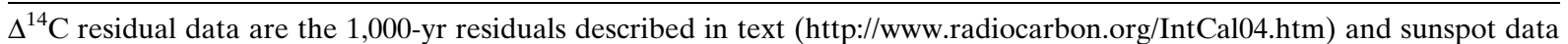
are from Solanki et al. (2004). All correlations are calculated at pentadal resolution except those involving the sunspot data, which are decadal. Correlations are calculated over the interval of the laminae thickness data, 1,420-2,835 yr B.P. Asterisks denote correlations significant at $>99.999 \%(* * *),>95 \%(* *)$, and $>90 \%(*)$

We calculated light and dark bundle durations for the interval in Core LT-00-01 that we interpret as annually varved (Fig. 6, Table 2). Dark bundles average $33.57 \pm 17.57 \mathrm{yr}$ in duration, and light bundles average $23.53 \pm 19.02$ yr. There is no correlation between the duration of a dark bundle interval and the succeeding light bundle interval $\left(r^{2}=0.0029\right)$, or between the duration of a light

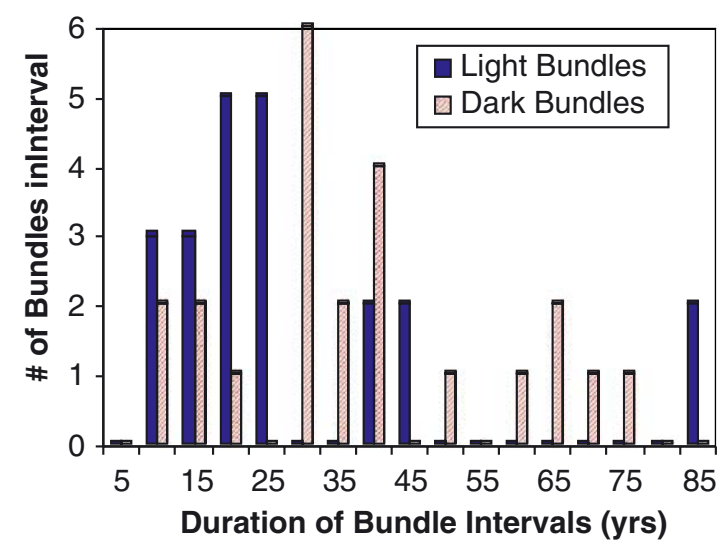

Fig. 6 Histograms of bundle durations in LT-00-02, binned into 5 year intervals. The dominant time scale of bundle duration is multidecadal ( $15-45$ years $)$ bundle and its succeeding dark bundle $\left(r^{2}=0.0014\right)$.

Prominent light bundles, composed of thicker laminae couplets, formed from 2,840-2,800, $2,770-2,730, \quad 2,580-2,540, \quad 2,360-2,320, \quad 2,250$ $2,170, \quad 1,840-1,810, \quad 1,770-1,740, \quad 1,600-1,570$, 1,520-1,490, and 1,460-1,420 cal. yr B.P. (rounded to the nearest decade). These are interspersed with prominent ( $\geq 30 \mathrm{yr}$ duration) dark bundles dating to $2,800-2,770,2,700-2,630,2,620-2,580$, $2,540-2,500, \quad 2,490-2,460, \quad 2,440-2,400, \quad 2,320$ $2,250, \quad 2,130-2,070, \quad 2,050-2,020, \quad 2,000-1,930$, $1,920-1,880, \quad 1,810-1,770, \quad 1,740-1,680, \quad 1,660-$ 1,630 , and generally between 1,450 and $1,550 \mathrm{yr}$ B.P.

These strong, multidecadal alternations between increased (light bundle) and decreased (dark bundle) sedimentation rates during both the dry and wet seasons suggests there may be a mechanism linking seasonal runoff and diatom productivity at multidecadal time scales which does not operate at the shorter, annual cycle scale. Furthermore, the lack of correlation between the duration of successive light and dark bundles implies that this mechanism does not 
have a "memory" of prior conditions driving bundle formation.

Spectral analysis of laminae records

Results of spectral analyses based on the varved interval of Core LT-00-01 are given in Fig. 7. For the log-transformed thickness data, significant spectral peaks occur at several sub-decadal to centennial periods for both light and dark halfcouplet thicknesses analyzed separately (Table 4). The most interesting feature of the spectral analysis is the contrast between our results at multidecade-century periods and results at decadal-interannual time scales. We observe strong coherency between significant light and dark half-couplet thicknesses at the multidecadal and longer time scales, but virtually no such coherency between light and dark half couplets at shorter time scales. Significant peaks occur through a broad range of time scales greater than a century for dark half couplets and $>33 \mathrm{yr}$ for light half couplets. A broad variance peak coherent between dark and light half-couplet thickness occurs at periods between $\sim 160$ and 670 years, with additional coherent peaks centered near 40 and 70 years. Bidecadal peaks for light half-couplets at $\sim 21.5$ years and for dark half-couplets centered at $\sim 26$ years may reflect the visually obvious bundling patterns observed in the gross lithostratigraphy of the core. Both light and dark half couplets also show significant quasidecadal ( $11 \mathrm{yr})$ peaks, although at these periods the peaks are not coherent. At higher frequencies
Fig. 7 Spectral analysis of ln-transformed light and dark laminae thickness data for LT-00-02. In each panel, the blue line represents the variance spectrum of the dark laminae thickness series and the maroon line represents that of the light laminae thickness series. The lower (green) line shows the coherency between the light and dark variance spectra. Light smooth lines represent $90 \%$ significance limits. (a) Entire spectrum analyzed. (b) Expanded view of decadal to century-scale variance shown in a. Shading/coloring conventions as in $\mathbf{a}$
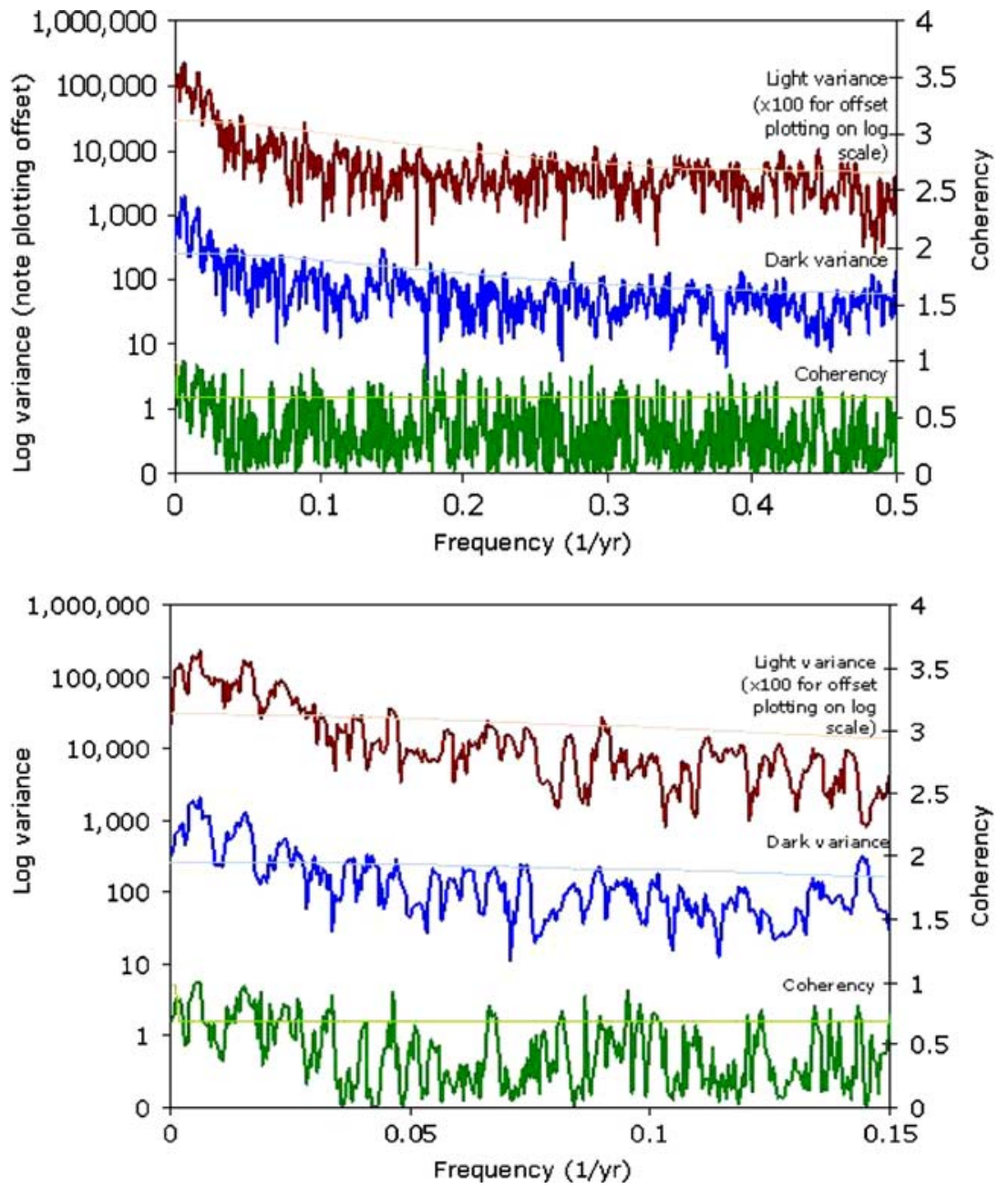
Table 4 Significant ( $>90 \%$ ) periods in spectral analysis of laminae half-couplet thickness (ln-transformed) data

\begin{tabular}{ll}
\hline Log dark peaks $(\mathrm{yr})$ & Log light peaks $(\mathrm{yr})$ \\
\hline$\geq 113$ & $\geq 33$ \\
$58-89$ & \\
$36-45$ & $21.3-22$ \\
$26.2-27$ & \\
$13.5-13.7$ & 11.1 \\
11.2 & \\
$6.6,6.9-7.0$ & 4.75 \\
$5.3,4.7,4.4$ & $3.8,3.4,3.3,3.0$ \\
$3.8,3.6,3.4,3.2,3.0$, & Many peaks in \\
Many peaks in & $2.0-3.0$ yr range \\
$2.0-3.0$ yr range &
\end{tabular}

light and dark half couplets display numerous, noncoherent peaks in the biennial-interannnual range.

\section{Comparison with solar forcing reconstructions}

We used the 1,000 -yr residual $\Delta^{14} \mathrm{C}$ data from the IntCal 2004 reconstruction (Reimer et al. 2004; http://www.radiocarbon.org/IntCal04.htm) and sunspot reconstructions from Solanki et al. (2004) to compare the laminae thickness records with solar forcing. Linear correlations between laminae and solar time series are weak in terms of variance explained, but reach $90-95 \%$ significance for the $\Delta^{14} \mathrm{C}$ comparisons (Table 3), indicating thinner dark and light layers during periods of lower solar input (higher $\Delta^{14} \mathrm{C}$ ). Cross-spectral analysis highlights the importance of multidecadal-centennial periods in all records, but shows significant coherence only at a period of $\sim 160 \mathrm{yr}$ (Fig. 8), not at the more clearly defined and widely recognized periods of solar variability (e.g. 200, $90 \mathrm{yr}$ ). Visual comparison of the solar and laminae thickness records (Fig. 9) reveals that major solar minima at $\sim 2,300$ and $\sim 2,700 \mathrm{yr}$ B.P. coincide with major laminae thickness minima.

\section{Discussion}

Century-scale variability: a solar connection?

The coherent century-scale variability evident in the time series analysis is particularly interesting

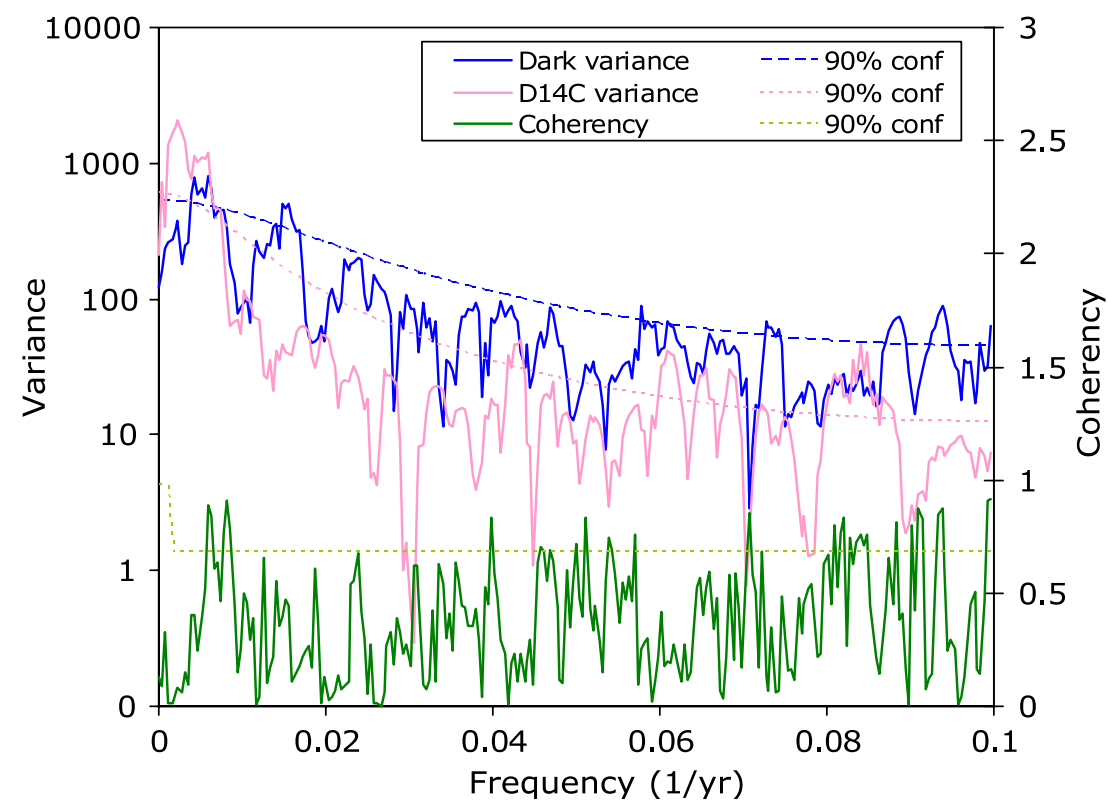

Fig. 8 Cross-spectral analysis of ln-transformed dark laminae thickness data for LT-00-02 compared with atmospheric $\Delta^{14} \mathrm{C}$ residual variance. The upper (blue) curve represents the variance spectrum of the dark laminae thickness record, and the middle (pink) curve represents the variance spectrum of D14C (Reimer et al. 2004); lighter dashed or dotted lines of the same colors indicate $90 \%$ significance for each. The lower (green) curve represents the coherence between these records, with $90 \%$ significance indicated (light green, dotted) 
Fig. 9 Decadally averaged laminae thickness data (plotted as ln thickness to make details of changes in thinner laminae clearer) compared to atmospheric $\Delta^{14} \mathrm{C}$ residuals (raw data with 1,000-yr moving average subtracted; http:// www.radiocarbon.org/ IntCal04.htm; Reimer et al. 2004). Note correspondence of radiocarbon peaks (solar minima) with thinner laminae for the largest solar anomalies at 2,300 and 2,700 cal yr B.P.

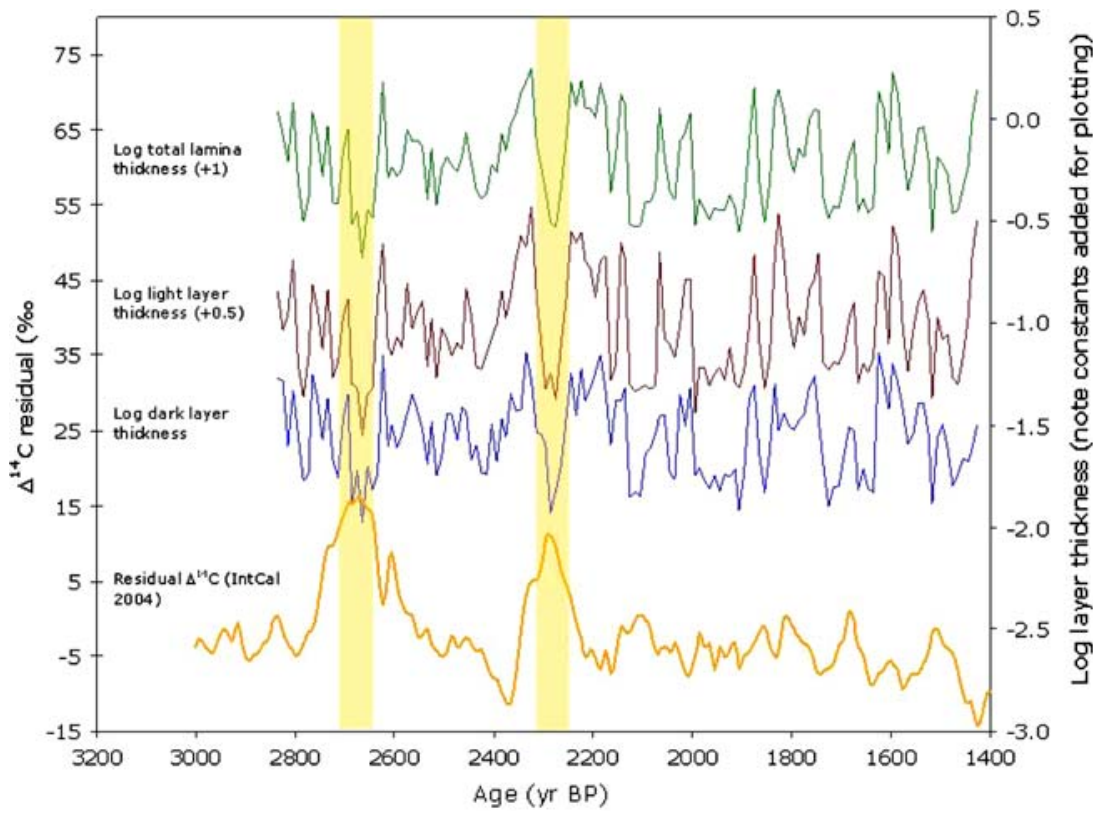

because it appears to match time scales of climatic variability observed elsewhere in the tropics. Quasi-periodic behavior in tropical and subtropical precipitation centered near a 206-208 yr period has been observed in several other highresolution paleorecords (Black et al. 1999; Verschuren et al. 2000; Neff et al. 2001; Hodell et al. 2001; Wang et al. 2005). This periodicity corresponds with the well-established Suess cycles in solar activity, as reflected by radiocarbon production records (Stuiver and Quay 1980; Damon and Jirikowic 1992). Over the period of our record, two large maxima in $\Delta^{14} \mathrm{C}$ (solar insolation minima) correspond closely to large negative anomalies in laminae thickness (Fig. 9). We obtain similar results using the sunspot reconstruction of Solanki et al. (2004), not shown. This suggests that solar forcing may be a major climatic determinant for precipitation during exceptional forcing events. However, the direction of this relationship (solar minima corresponding with precipitation minima) is opposite to that observed by Verschuren et al. (2000) for the last millennium at Lake Naivasha, Kenya, located $\sim 1,000 \mathrm{~km}$ northeast of our study site. NCAR GCM simulations also support solar minima corresponding with precipitation minima (CLIVAR/PAGES/IPCC Workshop Report
2003), and Stager et al. (2005) demonstrated both positive and inverse relationships between ${ }^{14} \mathrm{C}$ and the level of Lake Victoria over the past 1,000 years. Recent NCEP/NCAR reanalysis data covering the past $\sim 50$ years show a statistically significant correlation between solar maxima and stronger precipitation throughout the tropics (van Loon et al. 2004). Climatic reactions to solar forcing are likely to vary between locations as a result of relocation of atmospheric circulation cells, such that some areas may become wetter while others simultaneously dry (e.g. van Geel et al. 1996). However, within the constraints of our age model, five-year averaged laminae thickness records are only moderately correlated with actual $\Delta^{14} \mathrm{C}$ residuals or with sunspot activity for the study interval (Table 3). Although correlation coefficients are statistically significant between laminae parameters and the $\Delta^{14} \mathrm{C}$ residuals, the amount of variance explained is low. At multi-decadal to century time scales, we find that solar forcing of climate variability is only expressed during the most extreme solar events, in agreement with the findings of Russell and Johnson (2005) at Lake Edward ( 600 km north of our study site). However, our record differs from that of Russell and Johnson in that significant $\sim 11 \mathrm{yr}$ frequency peaks are evident in both 
our light and dark laminae thickness data (Table 4), suggesting that solar forcing may be more important at these time scales than was evident from the Lake Edward record.

Decadal-multidecadal variability

A growing body of evidence documents natural, apparently unforced decadal-multidecadal variability in other climate records, particularly in the tropics and the Pacific. Interdecadal variability strongly influences both the tropics and mid-latitudes of the Pacific (Mantua et al. 1997; Zhang et al. 1997; Garreaud and Battisti 1999; Newman et al. 2003; Deser et al. 2004) and extends into the tropical Indian Ocean (Power et al. 1999; Deser et al. 2004). Quasi-decadal climate variability, similar to that inferred from our record, has previously been observed in western Indian Ocean coral records, where it has been linked to decadal changes in ENSO (Cole et al. 2000; Urban et al. 2000). Damassa et al. (in press) observe that in earlier times, notably the 17 th century, a multidecadal mode dominated SST variability in the tropical western Indian Ocean; this variability correlates with reconstructions of ENSO, Pacific interdecadal variability, and northern hemisphere temperature. A global analysis of climate correlations with Pacific interdecadal variability (Mantua and Hare 2002) shows a significant relationship with rainfall in the northern Tanganyika basin. Variability at multidecadal time scales (ca. 21-89 yr periods, approximating the visual light/dark laminae bundles) may thus indicate a Pacific connection. Although Pacific interdecadal variability is not strictly periodic, it does vary at broadly bidecadal-multidecadal time scales, and paleoclimatic reconstructions of this index indicate quasidecadal, bidecadal, and multidecadal components. Thus we may be seeing an expression of Pacific interdecadal variability in our records of Tanganyika climate-particularly in the alternation of dark and light bundles on bidecadal and multidecadal time scales.

\section{Interannnual variability}

Our time series analyses record significant interannual variability on subdecadal timescales. We resolve periods down to 2-3 years and note substantial variability in this frequency band. Today, a significant 6-yr period in rainfall reflects the influence of ENSO teleconnections (Nicholson and Entekhabi 1987; Nicholson and Kim 1997; Nicholson 1999) and ENSO variability is reflected in interannual climate and fisheries variability in the Lake Tanganyika instrumental record (Plisnier 1997; Plisnier et al. 2000). The interannual variance in our results suggests a similar climatic regime between 1,500 and 2,800 B.P. In support, Moy et al. (2002) infer from a record of terrigenous sedimentation in an Ecuador lake that ENSO has established dominantly interannual variance by this time. However, the lack of coherence between our light and dark half couplet thickness in this subdecadal frequency band precludes a simple "ENSO-only" explanation that would influence both dark and light half couplet thicknesses. Furthermore, there is no good mechanistic explanation for why light halfcouplets (reflecting diatom productivity) should vary at ENSO-time scales: no relationship between ENSO and wind strength or direction is evident from instrumental records of Lake Tanganyika over the past few decades.

Implications for productivity

and nutrient cycling

The strong decade-century scale variations in light and dark laminae thickness are not only reflected visually in light and dark laminae bundles (Fig. 4) but are also evident geochemically (Table 2). Total phosphorus (TP) flux to the sediments is much higher during light bundle $\left(11.42 \pm 1.65 \mu \mathrm{g} \mathrm{cm}^{-2} \mathrm{yr}^{-1}\right)$ than dark bundle intervals $\left(6.04 \pm 1.11 \mu \mathrm{g} \mathrm{m}^{-2} \mathrm{yr}^{-1}\right)$. Changes in both sedimentation rates and TP between light and dark bundles occur simultaneously (to the best of our inference) and very rapidly (within a few years).

Whereas light and dark half-couplet thicknesses are uncorrelated on an annual or interannual scale, they are systematically both larger in light bundles than in dark bundles, revealing correlation on the multidecadal scale. This contrast suggests that different mechanisms are regulating diatom productivity and/or terrigenous sedimentation at annual (varve) vs. multidecadal (bundle) 
scales. We argue that dark half couplet thickness patterns are still most likely driven by runoff intensity at the bundle scale, and therefore it is the mechanism for productivity that has changed at longer time scales. In this regard it is significant that interannual variations in wind and rain are uncorrelated in this region. Multiple processes drive interannual precipitation variability in East Africa, and only some of these are correlated with dry season windiness (Tourre and White 1994; Plisnier 1997; Plisnier et al. 2000). On an annual basis, dry season windiness drives upwelling and internal seiche development that is seasonally coupled to increased diatom productivity through nutrient loading from deep-water upwelling. Rainy season input of nutrients has little effect on this process because the annual input of nutrients from the watershed is small compared to that contributed by upwelling and turbulence (internal loading). But what would cause light laminae thickness and productivity to vary in concert with runoff at decade to century time scales?

Three possible linkages exist. First, fluctuations in sediment thicknesses might reflect long-term changes in lake level and subsequent sediment supply. However, other records indicate that Lake Tanganyika's level only varied by $5-10 \mathrm{~m}$ during this part of the Late Holocene (Cohen et al. 1997).

Second, changes in productivity may be driven by strengthening or weakening of lake stratification as it affects the upwelling of nutrient rich waters, a plausible explanation for variability on longer time scales, and one previously invoked for long-term variability in tropical lake productivity and for productivity changes over the last century related to regional warming (Stager 1998; O'Reilly et al. 2003). Other factors being equal, decreased mean water column temperatures in Lake Tanganyika would reduce stratification and enhance circulation, nutrient regeneration, and therefore productivity. Correlated light/dark half couplet thicknesses would imply that overall cooler intervals at these time scales were also wetter. However, this model is at odds with historical observations and instrumental records in East Africa for the past several centuries, when cooler intervals have generally been much drier (Nicholson 1996, 1998).
The third and most likely explanation of the decade-century scale coherence is that precipitation and runoff ultimately regulate productivity in Lake Tanganyika at these time scales, as has been argued for other tropical African lakes at longer time scales (Johnson et al. 2002), by determining recharge of terrestrially derived nutrients to the lake (Hecky et al. 1996). During long periods of increased precipitation and runoff, recharge of the metalimnion nutrient pool is accelerated. The availability of nutrients for diatom production on an annual basis would still be regulated by seasonal windiness and upwelling, and subdecadal variation in light and dark laminae thickness would remain uncorrelated. However, the baseline of production during these periods would be elevated by the larger annual flux of phosphates during the rainy season, increasing average production in both windy and nonwindy years (TP data, Table 2). A useful analogy to this process would be to consider the metalimnion of Lake Tanganyika as a rechargeable battery, which annually provides "energy" to the lake surface waters (nutrients), in which the annual flow is regulated by short-term variation in the quality of the "wiring" (windiness, seasonal temperature variation). The battery must be periodically recharged (with terrestrial nutrient supply) or it will run down (as seen during arid intervals) (Fig. 10).

Rainfall and river inputs of total, dissolved, and soluble reactive phosphorus (TP, TDP, SRP respectively) have been characterized for Lake Tanganyika (Kimbadi et al. 1999; Langenberg et al. 2003b, FAO/FINNIDA unpubl. data). These data show that phosphorus concentrations for the two major rivers (Rusizi and Malagarasi) and for minor rivers are usually similar from wet to dry seasons (TDP \& SRP for Rusizi, TP \& SRP-Malagarasi) or are greater during the rainy season (TP for Rusizi and minor rivers, TDP for Malagarasi). The only instance where dry season concentrations for inflows exceed those of rainy seasons was for TDP and SRP for minor rivers, and this comprises a relatively small component of total lake P inputs. Existing data (Hecky et al. 1991; Edmond et al. 1993; Kimbadi et al. 1999; Langenberg et al. 2003b) on major phosphorus sources and sinks can be contrasted with our hypothesized wet and dry climate conditions. The 


\section{Dry Climate/Low Productivity Conditions}

River and Rain P Inputs Substantially

Reduced Retative To Modem
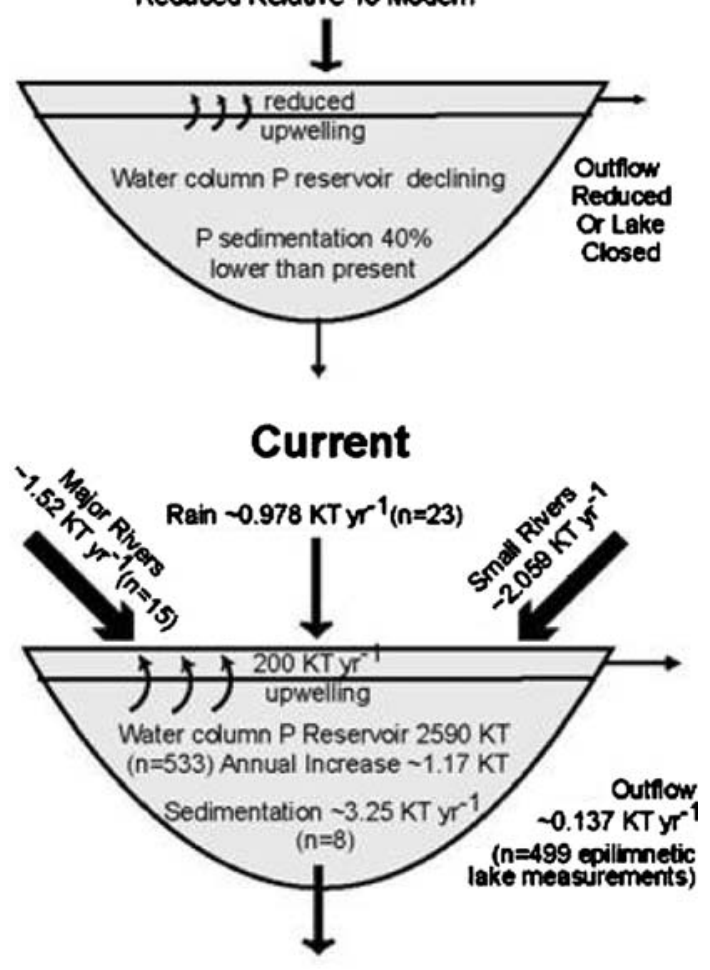

Wet Climate/High Productivity
Conditions

River and Rain P inputs Substantially Increased

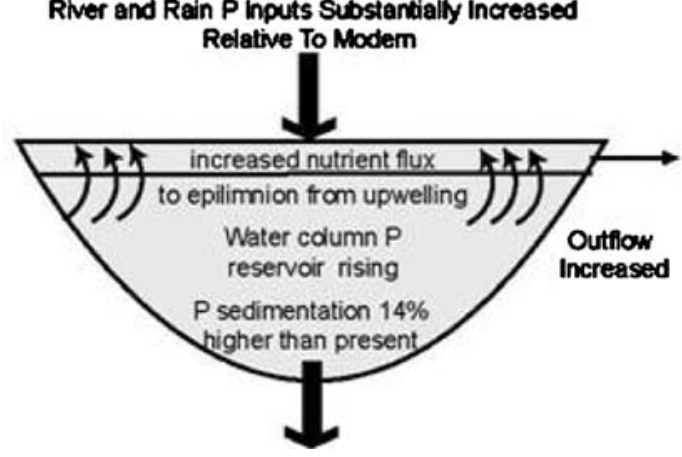

Fig. 10 Box model of TP inputs and outputs for Lake Tanganyika under current conditions, and hypothesized trends for arid (thin-dark bundle) and wet (thick light bundle) intervals

excess of modern precipitation and runoff inputs over outflow implies a current TP increase of approximately $\sim 4.42 \mathrm{kt} \mathrm{yr}^{-1}$. Of this total, $3.25 \mathrm{kt} \mathrm{yr}^{-1}$ is sedimented, based on TP accumu- lation rate data from well dated cores throughout the lake, yielding an annual increase of $1.17 \mathrm{kt} \mathrm{yr}^{-1}$ in the water column, or about $0.04 \%$ of the Lake Tanganyika phosphorus pool. Repeated deep water column profiles and more sediment $\mathrm{P}$ characterization are needed to verify if phosphorus concentrations are rising in the lake at this rate, especially given the rapidity with which other Great Lakes in Africa have both warmed and undergone cultural eutrophication (Hecky 1993; Lehman et al. 1998). Our data imply that it is not possible to construct a simple equilibrium model of phosphate inputs under varying runoff regimes using the modern, nonequilibrium lake and watershed conditions. However, given that surface runoff rates are at least $2-8 \times$ higher in the Lake Tanganyika watershed during the rainy season than in the dry season, and perhaps even more (Sichingabula 1999; Kakogozo et al. 2000; Nkotagu and Mwambo 2000), and that higher runoff rates in the Rusizi and minor rivers (55\% of total) are strongly correlated with much higher concentrations of eroded phosphorus, it is clear that by increasing the rate of precipitation over a short (seasonal) time scale, it is possible to increase the erosion rate of $\mathrm{P}$ from the watersheds, consistent with our model's longer time scale requirements.

\section{Conclusions}

Based on the climate-nutrient recharge model proposed here, we interpret the decade-century scale variation in laminar thickness patterns to reflect alternation between drought and wet conditions, linked with prolonged episodes of lower or higher diatom productivity (Fig. 5). Several prominent ( $\geq 30 \mathrm{yr}$ duration) wetter-thanaverage intervals (rounded to nearest decade), from $2,840-2,800, \quad 2,770-2,730, \quad 2,580-2,540$, $2,360-2,320, \quad 2,250-2,170, \quad 1,840-1,810, \quad 1,770$ $1,740, \quad 1,600-1,570, \quad 1,520-1,490$, and 1,460 1,420 cal. yr B.P. are interspersed with prolonged ( $\geq 30 \mathrm{yr}$ duration) drought episodes $(2,800-2,770$, $2,700-2,630, \quad 2,620-2,580, \quad 2,540-2,500, \quad 2,490$ $2,460, \quad 2,440-2,400, \quad 2,320-2,250, \quad 2,130-2,070$, $2,050-2,020, \quad 2,000-1,930, \quad 1,920-1,880, \quad 1,810$ $1,770,1,740-1,680,1,660-1,630$, and generally 
between 1,450 and 1,550 yr B.P.). The latter event may correlate with palynological and charcoal evidence for a rapid shift to more arid conditions at Lake Masoko, southeast of Lake Tanganyika (Thevenon et al. 2003), although the great differences in sampling resolution between the studies (subannual for our study vs. centennial scale for Lake Masoko) precludes a detailed comparison. Moreover, the transitions between these states appear to be quite abrupt, as interpreted from the rapid shifts in average varve couplet thicknesses at bundle boundaries. Some of these events (e.g. drought intervals around 2,630-2,700, 1,930-2,000 and 1,450-1,550 yr B.P. (see Fig. 5) appear to be of regional extent, based on comparisons with other high resolution paleoclimate records from East-Central Africa (Russell et al. 2003; Russell and Johnson 2005; Stager et al. 2003).

The coherency between light and dark half couplet thicknesses (productivity and rainfall, respectively) at multidecadal and longer time scales is consistent with our model that wet-dry cycles drive major changes in internal nutrient availability and productivity in Lake Tanganyika. We propose that this linkage occurs because the limiting role played by phosphorus, ultimately derived from erosion in the watershed, is only expressed at long time scales. In contrast, internal nutrient loading, the dominant process at subdecadal (i.e. most instrumental) time scales is not tightly coupled to wet-dry variability in climate, explaining the lack of coherence in light-dark half couplet thicknesses at this scale.

Our results are not consistent with a strong linear response of regional climate to solar forcing. Although the time scales are generally consistent with such an interpretation, they are not supported by our frequency-domain analysis. Large solar anomalies do appear to produce a response, with solar minima correlating with thinner laminae (i.e. drought conditions). Although this finding is the opposite of what has been recorded for other lakes in East Africa, it is consistent with the direction of response noted in modern climate observational and modeling studies. Outside the strongest two solar anoma- lies, the relationship between solar and laminae thickness records is weak. We can conclude that large solar anomalies produce a climate response, but that smaller variations either produce no response, or whatever responses are generated may be masked by other factors influencing regional climate. Variability at the bundle (bidecadalcentennial) scale may be tied, instead, to naturally occurring but poorly understood modes of internal climate system behavior at these time scales, notably related to Pacific interdecadal variance. At interannual scales, we observe significant variability in both light and dark half couplet data which is not coherent. The dark half couplet record may provide a record of ENSO influence on rainfall in the region. However, there is no simple mechanistic explanation for why the light couplets should reflect ENSO.

Our finding that regional climate variability is transmitted to diatom productivity in the Lake Tanganyika ecosystem at decadal-century time scales has direct economic and biodiversity significance for the region. Lake Tanganyika currently produces approximately 200,000 $\mathrm{t} \mathrm{yr}^{-1}$ of fish (Coenen et al. 1998), a critical resource for the regional economy of East-Central Africa. Lake Tanganyika fisheries production is closely linked to nutrient upwelling, which varies seasonally (Plisnier et al. 1999), because the fish depend strongly on primary (diatom) production. However, the longer temporal perspective provided by our data shows that climate-induced changes in productivity must be factored into our understanding of fishery resources. Recent observations suggest that warming of the East African lakes on the order of $0.5^{\circ} \mathrm{C}$ has occurred since the 1950s (Plisnier 1997, 2000). The shortterm effects of such warming are an intensification of thermal stratification (O'Reilly et al. 2003; Verburg et al. 2003) and a probable reduction in primary productivity caused by reduced internal nutrient supply (O'Reilly et al. 2003). This effect is likely to couple with the long-term variations in lake productivity linked to regional precipitation documented here, severely reducing watershed nutrient renewal in Lake Tanganyika and similar deep lakes during future prolonged droughts. 
Acknowledgements We thank the Tanzania Fisheries Research Institute, the Tanzanian Council on Science and Technology, FAO/FINNIDA/LTR, the students and staff of the Nyanza Project, the crew of the $M / V$ Maman Benita, and colleagues at the University of Dar es Salaam for help with this project and access to unpublished data. We are grateful to M. Mann for discussion of spectral analyses and C. Clark for assistance with climate data. We also thank J. Curt Stager and William Last for their many valuable comments on an earlier version of this manuscript. This research was financed by NSF (grant nos. ATM9619458 and ATM0223920) and the Lake Tanganyika Biodiversity Project. JEC acknowledges NSF support in the form of a CAREER grant on decadal variability. This is contribution \#168 of the International Decade of East African Lakes (IDEAL).

\section{References}

Anderson RY, Dean WE (1988) Lacustrine varve formation through time. Palaeogeogr Palaeoclimatol Palaeoecol 62:215-235

Birks HH, Battarbee RW, Birks HJB, Bradshaw EG, Brooks SJ, Duigan CA, Jones VJ, Lemdahl G, Peglar SM, Solem JO, Solhøy IW, Stalsberg MK (2000) The development of the aquatic ecosystem at Kråkenes Lake, western Norway, during the late-glacial and early-Holocene-a synthesis. J Paleolimnol 23:91-114

Black DE, Peterson LC, Overpeck JT, Kaplan A, Evans MN, Kashgarian M (1999) Eight centuries of North Atlantic Ocean atmospheric variability. Science 286: 709-1713

CLIVAR/PAGES/IPCC Workshop (2003) A multi-millennia perspective on drought and implications for the future. CLIVAR/PAGES, Southampton, UK; Bern, Switzerland

Coenen EJ, Paffen P, Nikomeze E (1998) Catch per unit of effort (CPUE) study for different areas and fishing gears of Lake Tanganyika: FAO/FINNIDA. Research for the Management of the Fisheries of Lake Tanganyika. GCP/RAF/271/FIN-TD/80, UN-FAO, Rome, Italy

Cohen AS, Talbot MR, Awramik SM, Dettman DL, Abell P (1997) Lake level and paleoenvironmental history of Lake Tanganyika, Africa, as inferred from late Holocene and modern stromatolites. Geol Soc Am Bull 109:444-460

Cohen AS, Palacios-Fest MR, Msaky ES, Alin SR, McKee B, O'Reilly CM, Dettman DL, Nkotagu H, Lezzar KE (2005) Paleolimnological investigations of anthropogenic environmental change in Lake Tanganyika: IX. Summary of paleorecords of environmental change and catchment deforestation at Lake Tanganyika and impacts on the Lake Tanganyika ecosystem. J Paleolimnol 34:125-145

Cole JE, Dunbar RB, McClanahan TR, Muthiga N (2000) Tropical Pacific forcing of decadal variability in the western Indian Ocean over the past two centuries. Science 287:617-619
Damassa TD, Cole JE, Barnett HR, Ault TR, McClanahan TR (in press). Enhanced multidecadal climate variability in the 17 th century from coral isotope records in the western Indian Ocean. Paleoceanography

Damon PE, Jirikowic JL (1992) The sun as a low-frequency harmonic oscillator. Radiocarbon 34:199-205

Deser C, Phillips AS, Hurrell JW (2004) Pacific interdecadal climate variability: linkages between the tropics and the North Pacific during boreal winter since 1900. J Climate 17:3109-3124

Edmond JM, Stallard RF, Craig H, Weiss RF, Coulter GW (1993) Nutrient chemistry of the water column of Lake Tanganyika. Limnol Oceanogr 38:725-738

François R, Pilskaln CH, Altabet MA (1996) Seasonal variation in the nitrogen isotopic composition of sediment trap materials collected in Lake Malawi. In: Johnson TC, Odada EO (eds) The limnology, climatology and paleoclimatology of the East African lakes. Gordon and Breach Publishers, Amsterdam, Netherlands, pp 241-250

Francus P, Cocquyt C, Sturm M (2003) High resolution study of laminated facies of sediment cores from Lake Tanganyika: are they annual? IXth Intl Paleolimnol Symp, Helsinki, Finland. Abstr. w/prog

Garreaud RD, Battisti DS (1999) Interannual (ENSO) and interdecadal (ENSO-like) variability in the Southern Hemisphere tropospheric circulation. J Climate 12:2113-2123

Hecky RE (1991) The pelagic ecosystem. In: Coulter GW (ed) Lake Tanganyika and its life. Oxford Univ. Press, Oxford, UK, pp 90-110

Hecky RE (1993) The eutrophication of Lake Victoria. Verh Internat Verein Limnol 25:39-48

Hecky RE, Bootsma HA, Mugidde RM , Bugenyi FWB (1996) Phosphorus pumps, nitrogen sinks, and silicon drains: plumbing nutrients in the African Great Lakes. In: Johnson TC, Odada EO (eds) The limnology, climatology and paleoclimatology of the East African lakes. Gordon and Breach Publishers, Amsterdam, Netherlands, pp 205-224

Hecky RE, Spigel RH, Coulter GW (1991) The nutrient regime. In: Coulter GW (ed) Lake Tanganyika and its life. Oxford Univ. Press, Oxford, UK, pp 76-89

Hodell DA, Brenner M, Curtis JH, Guilderson T (2001) Solar forcing of drought frequency in the Maya lowlands. Science 292:367-1370

Imberger J, Patterson JC (1990) Physical limnology. Adv Appl Mech 27:303-475

Johnson TC, Barry SL, Chan Y, Wilkinson P (2001) Decadal record of climate variability spanning the past $700 \mathrm{yr}$ in the Southern Tropics of East Africa. Geology 29:83-86

Johnson TC, Brown ET, McManus J, Barry S, Barker P, Gasse F (2002) A high-resolution paleoclimate record spanning the past 25,000 years in southern East Africa. Science 295:113-114, 131-132

Kakogozo K, Mwenyemaile B, Drieu O (eds) (2000) Etude Hydrologique du Bassin Nord-Ouest du Lac Tanganyika (R.D. Congo). Final Report Series, Lake Tanganyika Biodiversity Project, Natural Resources Institute, Chatham, UK 
Kimbadi S, Vandelannoote A, Deelstra H, Mbemba M, Ollevier F (1999) Chemical composition of the small rivers of the north-western part of Lake Tanganyika. Hydrobiologia 407:75-80

Langenberg VT, Sarvala J, Roijackers R (2003a) Effect of wind induced water movements on nutrients, chlorophyll- $a$ and primary production in Lake Tanganyika. Aquat Ecosyst Health Mgmt 6:279-288

Langenberg VT, Nyamushahu S, Roijackers R, Koelmans AA (2003b) External nutrient sources for Lake Tanganyika. J Great Lakes Res 29(Suppl. 2):169-180

Lehman JT, Mugidde R, Lehman DA (1998) Lake Victoria plankton ecology: Mixing depth and climate driven control of lake condition. In: Lehman JT (ed) Environmental Change and Response in East African Lakes. Kluwer Acad. Dordrecht, Netherlands, pp 99116

Lotter AF, Sturm M, Teranes JL, Wehrli B (1997) Varve formation since 1885 and high resolution varve analyses in hypereutrophic Baldegersee (Switzerland). Aquat Sci 59:304-325

Mann M, Lees J (1996) Robust estimation of background noise and signal detection in climate time series. Climate Change 33:409-445

Mantua NJ, Hare SR, Zhang Y, Wallace JM, Francis RC (1997) A Pacific interdecadal oscillation with impacts on salmon production. Bull Am Meteorol Soc 78:1069-1079

Mantua NJ, Hare SR (2002) The Pacific decadal oscillation. J Oceanogr 58:35-44

Mölsä H, Sarvala J, Badende S, Chitamwebwa D, Kanyaru R, Mulimbwa M, Mwape L (2002) Ecosystem monitoring in the development of sustainable fisheries in Lake Tanganyika. Aquat Ecosyst Health Mgmt 5:267-281

Moy CM, Seltzer GO, Rodbell DT, Anderson DM (2002) Variability of El Nio/Southern Oscillation activity at millennial timescales during the Holocene epoch. Nature 420:162-165

Neff U, Burns SJ, Mangini A, Mudelsee M, Fleitman D, Matter A (2001) Strong coherence between solar variability and the monsoon in Oman between 9 and 6 kyr ago. Nature 411:290-293

Newman M, Compo GP, Alexander MA (2003) ENSOforced variability of the Pacific decadal oscillation. J Climate 16:3853-3857

Nicholson SE (1996) A review of climate dynamics and climate variability in Eastern Africa. In: Johnson TC, Odada EO (eds) The Limnology, Climatology and Paleoclimatology of the East African Lakes. Gordon and Breach Publ, Amsterdam, Netherlands, pp 25-56

Nicholson SE (1998) Historical fluctuations of Lake Victoria and other lakes in the northern rift valley of East Africa. In: Lehman JT (ed) Environmental Change and Response in East African Lakes. Kluwer-Academic, Dordrecht Netherlands, pp 7-29

Nicholson SE (1999) Historical and modern fluctuations of Lakes Tanganyika and Rukwa and their relationship to rainfall variability. Climatic Change 41:53-71
Nicholson SE, Entekhabi D (1987) Rainfall variability in equatorial and southern Africa. Relationships with sea-surface temperatures along the southwestern coast of Africa. J Clim Appl Meteorol 26:561-577

Nicholson SE, Kim JY (1997) The relationship of the El Nio-Southern Oscillation to African rainfall. Intl J Climatol 17:117-135

Nkotagu H, Mwambo K (2000) Hydrology of selected watersheds along the Lake Tanganyika shoreline: final report series, Lake Tanganyika Biodiversity Project. Natural Resources Inst, Chatham, UK

O'Reilly CM, Alin SR, Plisnier PD, Cohen AS, McKee BA (2003) Climate change decreases aquatic productivity of Lake Tanganyika, Africa. Nature 424:766-768

Palacios-Fest MR, Cohen AS, Lezzar KE, Nahimana L, Tanner BM (2005a) Paleolimnological investigations of anthropogenic environmental change in Lake Tanganyika: III. Physical stratigraphy and charcoal analysis. J Paleolimnol 34:31-49

Palacios-Fest MR, Cohen AS, Lezzar KE, Nahimana L, Tanner BM (2005b) Paleolimnological investigations of anthropogenic environmental change in Lake Tanganyika: IV. Lacustrine paleoecology. J Paleolimnol 34:51-71

Patterson G, Kachinjika O (1995) Limnology and phytoplankton ecology. In: Menz A (ed) The fishery potential and productivity of the pelagic zone of Lake Malawi/Niassa Natural Resources Institute, Overseas Development Administration. Hobbs The Printer Ltd., Totton, UK, pp 1-68

Pilskaln CH (1989) Seasonal particulate flux and sedimentation in Lake Malawi, East Africa. EOS 70:1130

Pilskaln C, Johnson TC (1991) Seasonal signals in Lake Malawi sediments. Limnol Oceanogr 36:544-557

Plisnier PD (1997) Climate, limnology and fisheries changes of Lake Tanganyika. FAO/FINNIDA Research for the management of the Fisheries of Lake Tanganyika. GCP/RAF/271/FIN/72, UN-FAO, Rome, Italy

Plisnier PD (2000) Recent climate and limnology changes in Lake Tanganyika. Verh Internat Verein Limnol 27:2670-2673

Plisnier PD, Langenberg VT, Mwape L, Chitamwebwa D, Tshibangu K, Coenen E (1996) Limnological sampling during an annual cycle at three stations on Lake Tanganyika. FINNIDA/FAO Report GCP/RAF/271/ FIN, UN-FAO, Rome, Italy

Plisnier PD, Chitamwebwa D, Mwape L, Tshibangu K, Langenberg VT, Coenen E (1999) Limnological annual cycle inferred from physical-chemical fluctuations at three stations of Lake Tanganyika. Hydrobiologia 407:45-58

Plisnier PD, Coenen EJ (2001) Pulsed and dampened annual limnological fluctuations in Lake Tanganyika. In: Munawar M, Hecky RE (eds) The great lakes of the world: food-web, health and integrity. Backhuys, Leiden, Netherlands, pp 83-96

Plisnier PD, Serneels S, Lambin EF (2000) Impact of ENSO on East African ecosystems: a multivariate analysis based on climate and remote sensing data. Global Ecol Biogeogr 9:481-497 
Power S, Tseitkin F, Mehta V, Lavery B, Torok S, Holbrook N (1999) Decadal climate variability in Australia during the twentieth century. Intl J Climatol 19:169-184

Reimer PJ, Baillie MGL, Bard E, Bayliss A, Beck JW, Bertrand CJH, Blackwell PG, Buck CE, Burr GS, Cutler KB, Damon PE, Edwards RL, Fairbanks RG, Friedrich M, Guilderson TP, Hogg AG, Hughen KA, Kromer B, McCormac FG, Manning SW, Bronk RC, Reimer RW, Remmele S, Southon JR, Stuiver M, Talamo S, Taylor FW, van der Plicht J, Weyhenmeyer CE (2004) IntCal04: terrestrial radiocarbon age calibration, 26-0 ka B.P. Radiocarbon 46:1029-1058

Russell JM, Johnson TC, Kelts KR, Laerdal T, Talbot MR (2003) An 11,000-year lithostratigraphic and paleohydrologic record from equatorial Africa: Lake Edward, Uganda Congo. Palaeogeog Palaeoclim Palaeoecol 193:25-49

Russell JM, Johnson TC (2005) A high-resolution geochemical record from Lake Edward, Uganda Congo and the timing and causes of tropical African drought during the late Holocene. Quat Sci Rev 24:1375-1389

Sichingabula H (1999) Analysis and results of discharge and sediment monitoring activities in the southern Lake Tanganyika basin, Zambia. Final Report Series, Lake Tanganyika Biodiversity Project, Natural Resources Inst., Chatham, UK

Solanki SK, Usoskin IG, Kromer B, Schüssler M, Beer J (2004) Unusual activity of the Sun during recent decades compared to the previous 11,000 years. Nature 431:1084-1087

Stager JC (1998) Ancient analogues for recent environmental changes at Lake Victoria, Africa. In: Lehman JT (ed) Environmental change and response in East African lakes. Kluwer-Academic, Dordrecht, Netherlands, pp 37-46

Stager JC, Cumming BF, Meeker LD (2003) A 10,000-year high-resolution diatom record from Pilkington Bay, Lake Victoria, East Africa. Quat Res 59:172-181

Stager JC, Ryves D, Cumming BF, Meeker LD, Beer J (2005) Solar variability and the levels of Lake Victoria, East Africa, during the last millennium. J Paleolimnol 33:243-251

Stuiver M, Quay PD (1980) Changes in atmospheric ${ }^{14} \mathrm{C}$ attributed to a variable sun. Science 207:11-19

Stuiver M, Reimer PJ, Reimer R (2005) CALIB 5.0.1html. http://www.calib.org
Thevenon F, Williamson D, Vincens A, Taieb M, Merdaci O, Decobert M, Buchet G (2003) A late-Holocene charcoal record from Lake Masoko, SW Tanzania: climatic and anthropologic implications. The Holocene 13:785-792

Tian J, Brown TA, Hu FS (2005) Comparison of varve and ${ }^{14} \mathrm{C}$ chronologies from Steel Lake, Minnesota, USA. The Holocene 15:510-517

Toure YM, White WB (1994) Indian Ocean may have El Nio of its own. EOS Dec 13 1994:3

Urban FE, Cole JE, Overpeck JT (2000) Modification of tropical Pacific variability by its mean state inferred from a 155-year tropical Pacific coral record. Nature 407:989-993

van Geel B, Buurman J, Waterbolk HT (1996) Archaeological and palaeoecological indications of an abrupt climate change in The Netherlands, and evidence for climatological teleconnections around $2650 \mathrm{BP}$. J Quat Sci 11:451-460

van Loon H, Meehl GA, Arblaster JM (2004) A decadal solar effect in the tropics in July-August. J Atmos Solar Terr Phys 66:1767-1778

Verburg P, Hecky RE, Kling H (2003) Ecological consequences of a century of warming in Lake Tanganyika. Science 301:505-507

Verschuren D, Laird KR, Cumming BF (2000) Rainfall and drought in equatorial East Africa during the past 1,100 years. Nature 403:410-414

Wang Y, Cheng H, Edwards RL, He Y, Kong X, An Z, Wu J, Kelly MJ, Dykowski CA, Li X (2005) The Holocene Asian monsoon: links to solar changes and North Atlantic climate. Science 308:854-857

Wheeler CW, Overpeck JT, Arko J, Sharp WE (2002) The varved sediments of Lake Bosumtwi, Ghana and implications for a new chronology of West African hydrologic change during the Late Quaternary. AGU Ann Mtg, Abst w/prog

Zhang Y, Wallace JM, Battisti DS (1997) ENSO-like interdecadal variability: 1900-93. J Climate 10:10041020

Zilifi D, Eagle M (2000) Sediment cores from the Kalya platform, slope and horst: high resolution and longtime span paleolimnology and paleoclimate records. 2000 Nyanza Project Annual Report, University of Arizona, Tucson, USA, pp 20-23 (http:// www.geo.arizona.edu/nyanza/ZilifiEagle.pdf) 